OPEN ACCESS

Edited by:

Julie Wixey,

University of Queensland, Australia

Reviewed by:

Flora Wong,

Monash University, Australia

Eugene Dempsey,

University College Cork, Ireland

${ }^{*}$ Correspondence:

Subhabrata Mitra

subhabrata.mitra.13@ucl.ac.uk

Specialty section: This article was submitted to

Pediatric Neurology,

a section of the journal

Frontiers in Neurology

Received: 07 February 2020 Accepted: 17 April 2020

Published: 27 May 2020

Citation:

Mitra S, Bale G, Meek J, Tachtsidis I and Robertson NJ (2020) Cerebral

Near Infrared Spectroscopy

Monitoring in Term Infants With Hypoxic Ischemic Encephalopathy -A

Systematic Review.

Front. Neurol. 11:393.

doi: 10.3389/fneur.2020.00393

\section{Cerebral Near Infrared Spectroscopy Monitoring in Term Infants With Hypoxic Ischemic Encephalopathy-A Systematic Review}

\author{
Subhabrata Mitra ${ }^{1 *}$, Gemma Bale ${ }^{2}$, Judith Meek ${ }^{1}$, Ilias Tachtsidis ${ }^{2}$ and \\ Nicola J. Robertson ${ }^{1}$
}

${ }^{1}$ Neonatology, Institute for Women's Health, University College London, London, United Kingdom, ${ }^{2}$ Medical Physics and Biomedical Engineering, University College London, London, United Kingdom

Background: Neonatal hypoxic ischemic encephalopathy (HIE) remains a significant cause of mortality and morbidity worldwide. Cerebral near infrared spectroscopy (NIRS) can provide cot side continuous information about changes in brain hemodynamics, oxygenation and metabolism in real time.

Objective: To perform a systematic review of cerebral NIRS monitoring in term and near-term infants with HIE.

Search Methods: A systematic search was performed in Ovid EMBASE and Medline database from inception to November 2019. The search combined three broad categories: measurement (NIRS monitoring), disease condition [hypoxic ischemic encephalopathy (HIE)] and subject category (newborn infants) using a stepwise approach as per PRISMA guidance.

Selection Criteria: Only human studies published in English were included.

Data Collection and Analysis: Two authors independently selected, assessed the quality, and extracted data from the studies for this review.

Results: Forty-seven studies on term and near-term infants following HIE were identified. Most studies measured multi-distance NIRS based cerebral tissue saturation using monitors that are referred to as cerebral oximeters. Thirty-nine studies were published since 2010; eight studies were published before this. Fifteen studies reviewed the neurodevelopmental outcome in relation to NIRS findings. No randomized study was identified.

Conclusion: Commercial NIRS cerebral oximeters can provide important information regarding changes in cerebral oxygenation and hemodynamics following $\mathrm{HIE}$ and can be particularly helpful when used in combination with other neuromonitoring tools. Optical measurements of brain metabolism using broadband NIRS and cerebral blood flow using 
diffuse correlation spectroscopy add additional pathophysiological information. Further randomized clinical trials and large observational studies are necessary with proper study design to assess the utility of NIRS in predicting neurodevelopmental outcome and guiding therapeutic interventions.

Keywords: neonate, hypoxic ischemic encephalopathy, oxygenation, metabolism, near infrared spectroscopy

\section{INTRODUCTION}

The current practice of therapeutic hypothermia (TH) has reduced the disability rates and the severity spectrum of cerebral palsy in newborn infants with hypoxic ischaemic encephalopathy (HIE). Infants with HIE are routinely monitored in the neonatal intensive care unit (NICU) with electroencephalography (EEG) or amplitude integrated EEG (aEEG) and cranial ultrasound (CrUSS) during $\mathrm{TH}$ to detect seizures, investigate the severity of the injury and inform prognosis. Brain magnetic resonance imaging (MRI) and spectroscopy (MRS) are gold standard tools for prognostication of injury and are optimally performed after completion of TH. However, these current technologies do not offer all the necessary physiological information that is needed for a continuous assessment of the changes in the newborn brain.

Following perinatal hypoxia-ischaemia, significant cerebral haemodynamic and metabolic derangements evolve over time (1-3). This evolution is associated with changes in the brain energy state and underlying neurochemical and neurotoxic state. Following acute hypoxia ischaemia (HI), brain high energy metabolites decrease with a reduction in CBF. Oxidative metabolism appears to recover after resuscitation along with improvement in brain perfusion but a period of hypoperfusion persists in the latent phase (up to $24 \mathrm{~h}$ following injury). Without any intervention, mitochondrial failure and cell death start in the secondary phase (persisting for days after birth) together with a state of hyperperfusion. Over the next few weeks and months, cerebral hemodynamic and metabolic abnormalities gradually normalize despite pathological processes persisting in this tertiary phase of injury. The degree of deranged cerebral oxidative metabolism following HIE can be identified using magnetic resonance spectroscopy (MRS) $(4,5)$.

Cerebral NIRS has several advantages as a neuromonitoring tool in the neonatal intensive care unit (NICU) and can be combined with aEEG/EEG monitoring. Its application is easy and quick. The monitoring can be continuous over a long period of time. NIRS can continuously monitor CBF, oxygenation, and metabolism at the cot side from the early stages after birth, with the potential to provide information on the severity of the evolving injury and outcome. NIRS uses the relative transparency of biological tissue in the near infrared (NIR) region of light $(700-1,000 \mathrm{~nm})$. In comparison to adults and older children, the thinner skin and skull thickness in newborn infants allows a better depth penetration of brain tissue and make the technique an ideal neuromonitoring tool for newborn infants. Hemoglobin is one of the compounds (chromophores) in the human body that absorbs light. The absorption spectra of oxygenated and de-oxygenated hemoglobin $\left(\mathrm{HbO}_{2}\right.$ and $\left.\mathrm{HHb}\right)$ are different in the near-infrared region, allowing changes in concentration to be individually monitored using NIRS. Total hemoglobin $\left(\mathrm{HbT}=\mathrm{HbO}_{2}+\mathrm{HHb}\right)$ and hemoglobin difference $\left(\mathrm{HbD}=\mathrm{HbO}_{2}-\mathrm{HHb}\right)$ are derived parameters and have been used to represent changes in cerebral blood volume (CBV) and cerebral oxygenation, respectively. Most commercially available NIRS systems measure cerebral oxygenation or tissue saturation $\left(\mathrm{StO}_{2}, \mathrm{rScO}_{2}, \mathrm{TOI}, \mathrm{rSO}_{2}\right)$, which is the percentage ratio of $\mathrm{HbO}_{2}$ to $\mathrm{HbT}\left(\mathrm{HbO}_{2} / \mathrm{HbT}\right)$; these systems are often referred to as brain oximeters, with different manufactures implementing different NIRS techniques to derive brain tissue saturation (69 ). We will use the term cerebral oxygenation in this review and this measurement will be discussed in further detail later under "NIRS devices and methodology." In healthy term infants, irrespective of the mode of delivery, cerebral oxygenation is lowest at birth (between 40 and 56\%) (6-10) and gradually increases to reach $\sim 78 \%( \pm 7.9 \%)$ in the first $24 \mathrm{~h}$ (11). It stabilizes over the next few weeks between 55 and $85 \%$ (1214). Using the combined measurement of cerebral oxygenation and peripheral arterial oxygen saturation one can estimate fractional tissue oxygen extraction $\left(\mathrm{FTOE}=\mathrm{SaO}_{2}\right.$ - cerebral oxygenation $/ \mathrm{SaO}_{2}$ ). It represents the balance between oxygen delivery and oxygen consumption, a proxy marker of cerebral metabolism (15). An increase in FTOE indicates an increased extraction of oxygen by brain tissue, suggesting a higher oxygen consumption in relation to oxygen delivery. A decrease of FTOE, on the other hand suggests reduced use of oxygen by brain tissue in relation to supply. Neither cerebral oxygenation nor FTOE accurately reflects the cerebral metabolic rate of oxygen consumption $\left(\mathrm{CMRO}_{2}\right)$.

Beyond the NIRS measurements of hemoglobin oxygenation, another NIR chromophore is cytochrome c oxidase (CCO). It is the terminal electron acceptor in the electron transport chain (ETC) and is responsible for more than $90 \%$ of ATP production, thus providing important information related to the changes in mitochondrial oxidative metabolism. The absorption spectra of the CCO will depend on its redox state, which in turn will depend on oxygen and energetic substrate availability. The NIRS measurements of CCO attracted a great deal of attention in the 1980's (16-19) but accurate measurement of CCO proved challenging due to its low in vivo concentration. However, recent developments in optical methods have enabled this measurement in the NICU, as will be discussed later under "NIRS devices and methodology."

We performed a systematic review of NIRS measurements in term or near-term newborn infants with HIE. Although several NIRS reviews in the preterm population have been published $(6,20)$, there is no comprehensive review of NIRS in term 
infants with HIE. The aim of this work is to review the potential benefits of cerebral NIRS monitoring in newborn infants with HIE and the utility of different NIRS variables to prognosticate outcome (short term or long term). We present a review of different optical measurements: how these indices evolve over time and their relationship with outcome, monitoring of cerebral autoregulation using NIRS and the use of NIRS together with other neuromonitoring tools. A brief description of the basic methodology and technology used for cerebral NIRS is presented along with emerging technologies in this area.

\section{METHODS}

A stepwise approach was taken to identify articles from databases following the guidance from the Preferred Items for Systematic Reviews and Meta-analysis (PRISMA) statement (21).

\section{SEARCH STRATEGY}

Published articles were identified using a systematic search of Medline database and Ovid EMBASE from inception to November 2019. Articles were filtered with publications in English only. The search focused on publications related to cerebral oxygenation, perfusion and metabolism using single or multiple site NIRS in infants with HIE. The retrieved articles were further examined for any other relevant published reports. Websites of manufacturers of NIRS monitors were also screened during the search to capture any articles that might have been overlooked.

The search combined three broad categories: measurement (NIRS monitoring), disease condition [hypoxic ischemic encephalopathy (HIE)] and subject category (newborn infants). Search term included: brain metabolism, brain function, tissue metabolism, cerebral metabolism or oxygenation or hemodynamic or blood flow or volume, near infrared, near infrared spectroscopy, brain hypoxia or anoxia, perinatal hypoxia or ischemia, asphyxia neonatorum, brain ischemia, brain injury or damage, encephalopathy, neonatal encephalopathy, newborn(s), newborn babies, infant(s) and neonate, neonates and neonatal.

The search strategies for the review is presented in Table $\mathbf{1 .}$

\section{STUDY SELECTION}

Publications were included in the review if they presented original data discussing the use of NIRS in newborn term or near-term infants with HIE. The articles identified from the databases were screened for duplicity and were then evaluated using the publication title and abstracts. Full texts were examined where uncertainty was noted at this stage. Articles with preclinical studies and abstract-only publications (where a full-length article was not published in a peerreviewed journal) were excluded. Studies on human infants were included for the final analysis. Full texts were assessed for the remaining articles and publications were excluded if they did not present original data in the term newborn population (review articles, commentaries, and studies in preterm population). Studies included for the final review were then assessed for data collection.

\section{RESULTS}

The initial search identified 3,144 articles. After excluding duplicate articles, preclinical studies and abstract only publications, 66 articles were identified, all of which discussed NIRS measurement in human newborn infants after HIE. Full texts of these articles were reviewed, and a further 14 articles were excluded (review papers:11, and studies in preterm population: 3 ), leading to final inclusion of 52 original research studies on the term and near-term infants following HIE. Five studies presented changes in NIRS variables specifically during seizures following HIE and were excluded from this review leaving 47 studies for the final review. The PRISMA chart detailing the searching and inclusion of the articles for the review is presented in Figure 1. Basic characteristics and brief details of the studies are presented in Table 2. Thirty-nine studies have been published since 2010, compared to eight studies before 2010. Most of the studies (thirty-five) investigated the changes in cerebral oxygenation. Other optical indices were FTOE, CBF, $\mathrm{CMRO}_{2}, \mathrm{HbD}, \mathrm{HbT}$, oxCCO, markers of haemodynamic reactivity and metabolic reactivity. Fifteen different devices were used in these studies and eleven of them were commercially available (Figure 2). Eight recent studies used broadband NIRS (BNIRS) to investigate changes in cerebral metabolism using direct measurement of changes in the oxidation state of cytochrome c oxidase (oxCCO). Fifteen studies presented MRI or MRS evidence of injury as short term outcome for comparing with NIRS makers while an equivalent number of studies presented neurodevelopmental follow up data. Eight studies used combined neuromonitoring using NIRS and aEEG/EEG.

\section{DISCUSSION}

Over the last decade, there has been increasing focus on NIRS monitoring at the cot side in babies with HIE and how it can inform clinical management and prognosis (Table 2).

\section{NIRS DEVICES AND METHODOLOGY}

Fifteen different NIRS instruments were used in the included studies, of which 11 instruments were commercially available. Among the non-commercial systems, a BNIRS system was used in eight studies $(25-28,46,51-53)$, purpose-built to monitor concentration changes in oxCCO and hemoglobin parameters. A frequency-domain near-infrared spectroscopy (FD-NIRS) protocol in a customized commercial FD oximeter was used to measure cerebral oxygenation (35). This was also coupled with a diffuse correlation spectroscopy (DCS) system to measure an additional index of tissue CBF (41). Huang et al. used a prototype instrument (TSNIR-3, using SRS technology) to 
TABLE 1 | Search strategy for the systamtic review on EMBASE.

\section{Search strategy used for systematic review:}

1. ("exp brain metabolism") or ("brain function") or ("tissue metabolism") or ([cerebr adj3 (metabol* or oxygenation or hemodynamic* or "blood flow" or volume*)].mp. [mp=title, abstract, heading word, drug trade name, original title, device manufacturer, drug manufacturer, device trade name, keyword, floating subheading word, candidate term word]) or ("near infrared spectroscopy") or ((near infrared adj3 spectroscop*).mp. [mp=title, abstract, heading word, drug trade name, original title, device manufacturer, drug manufacturer, device trade name, keyword, floating subheading word, candidate term word]). (Result: 169743)

2. ("brain hypoxia") or ("exp brain ischemia") or [((cerebr* or brain*) adj3 ("brain damage" or encephalopath*)].mp. [mp=title, abstract, heading word, drug trade name, original title, device manufacturer, drug manufacturer, device trade name, keyword, floating subheading word, candidate term word]) or [((hypoxi or anoxi*) adj3 ("brain damage*" or "brain injur" or encephalopath*)].mp. [mp=title, abstract, heading word, drug trade name, original title, device manufacturer, drug manufacturer, device trade name, keyword, floating subheading word, candidate term word]) or ("perinatal asphyxia") or [(asphyxia* adj3 (newborn or baby or babies or infan ${ }^{\star}$ or neonat $\left.\left.{ }^{\star}\right)\right] . m p$. [mp=title, abstract, heading word, drug trade name, original title, device manufacturer, drug manufacturer, device trade name, keyword, floating subheading word, candidate term word]) or ((encephalopath* adj3 neonat*).mp. [mp=title, abstract, heading word, drug trade name, original title, device manufacturer, drug manufacturer, device trade name, keyword, floating subheading word, candidate term word]). (Result: 228291)

3. ('newborn') or ((newborn or baby or babies or infan* or neonat*).mp. [mp=title, abstract, heading word, drug trade name, original title, device manufacturer, drug manufacturer, device trade name, keyword, floating subheading word, candidate term word]). (Result: 1475873)

4. 1 and 2 and 3. (Result: 1671)

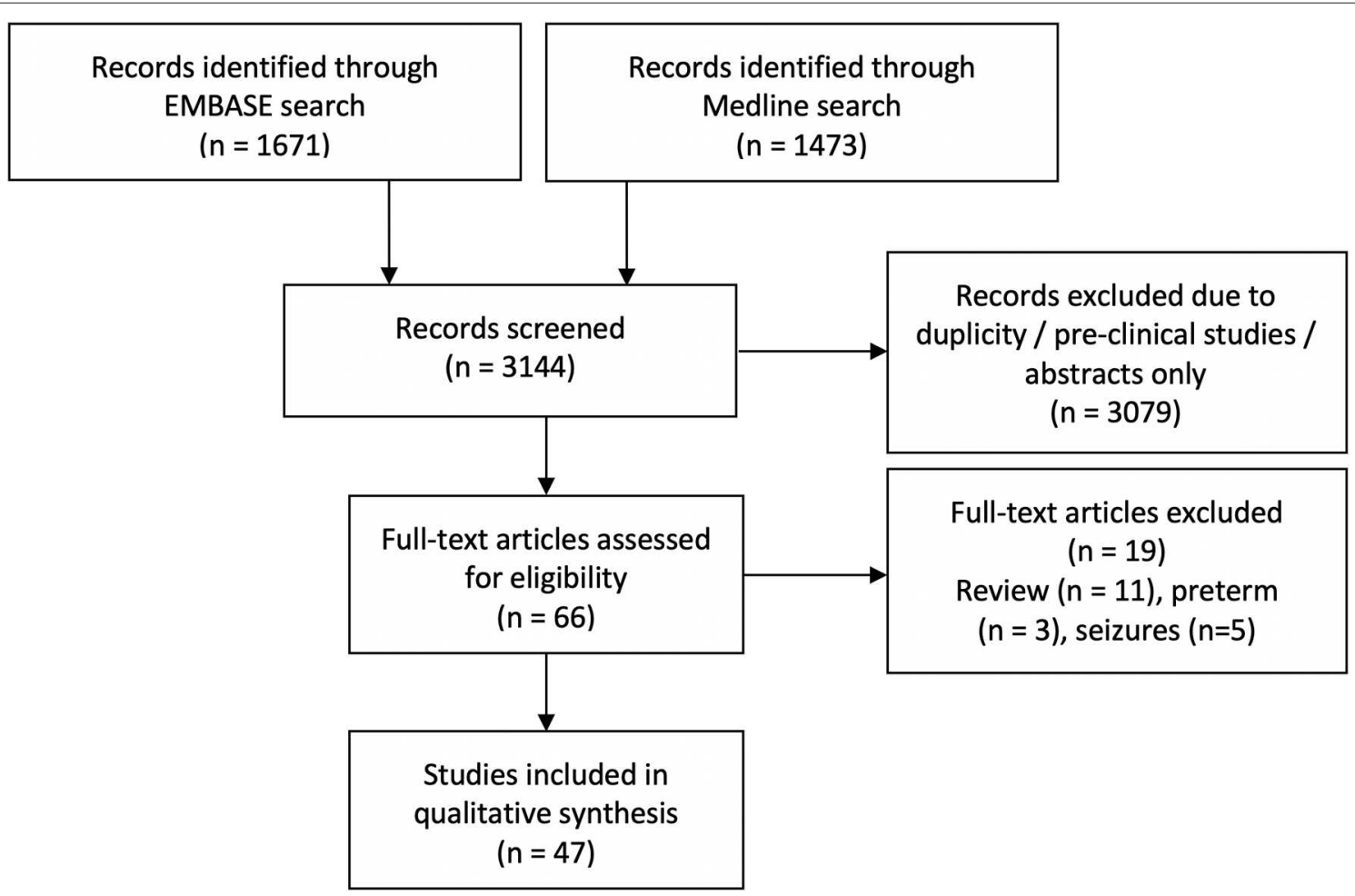

FIGURE 1 | PRISMA flow chart for the systamatic review.

compare cerebral oxygenation between healthy controls and HIE infants (44).

Three different modes of NIRS have been developed and used in systems in clinical settings-continuous wave, time resolved, and frequency domain NIRS.

Continuous wave $(\mathrm{CW})$ instruments were the earliest NIRS instruments to be developed and are the most commonly used. They use 2-4 discrete wavelength continuous sources [either laser or light-emitting diode (LED)] and measure the transmitted or reflected intensity through tissue. CW-NIRS systems are unable to separate attenuation of light due to absorption and scattering, so instead monitor changes in attenuation, and assume these are all due to absorption and that scattering remains stable within the measurement period. Using the modified Beer-Lambert law (66), these devices calculate changes in $\mathrm{HbO}_{2}$ and $\mathrm{HHb}$ concentration from an arbitrary baseline. Therefore, CW-NIRS protocols typically rely on variations in the signals or responses to specific (physiological or functional) stimuli.

In frequency domain NIRS (FD-NIRS) systems, the intensity of the emitted light is modulated at a particular frequency 
TABLE 2 | Study characteristics.

\begin{tabular}{|c|c|c|c|c|c|c|c|c|}
\hline $\begin{array}{l}\text { First author, } \\
\text { Year (Ref.) }\end{array}$ & $\begin{array}{l}\text { Study } \\
\text { design }\end{array}$ & $\begin{array}{l}\text { Gestation } \\
\text { (weeks) }\end{array}$ & $\begin{array}{l}\text { No of } \\
\text { subjects }\end{array}$ & Study aim & $\begin{array}{l}\text { NIRS device, } \\
\text { sensor }\end{array}$ & $\begin{array}{l}\text { Optode } \\
\text { placement on } \\
\text { head }\end{array}$ & $\begin{array}{l}\text { Duration } \\
\text { of study }\end{array}$ & Result \\
\hline Ancora et al. (22) & Observational & 39 & 1 & $\begin{array}{l}\text { To evaluate the time course of aEEG } \\
\text { and NIRS data before, during and } \\
\text { after cool cap treatment }\end{array}$ & NIRO 200 & Forehead & & $\begin{array}{l}\text { Early significant increase in THI and TOI before TH. TOI } \\
\text { improved with TH and remained stable during the rewarming } \\
\text { period }\end{array}$ \\
\hline Ancora et al. (23) & Observational & $\geq 36$ & 12 & $\begin{array}{l}\text { To evaluate the prognostic value NIRS } \\
\text { data in asphyxiated cooled infants }\end{array}$ & NIRO 200 & Forehead & $72 \mathrm{~h}$ & $\begin{array}{l}\text { Mean TOI at } 12 \mathrm{~h} \text { of life is significantly higher in infants who } \\
\text { develop a poor neurological outcome than in those with } \\
\text { normal outcome }\end{array}$ \\
\hline $\begin{array}{l}\text { Arriaga- } \\
\text { Redondo et al. } \\
\text { (24) }\end{array}$ & Observational & $\geq 36$ & 23 & $\begin{array}{l}\text { To assess the variability of cerebral } \\
\text { tissue oxygenation over time in infants } \\
\text { with } \mathrm{HIE}\end{array}$ & Invos 5100 & Forehead & $100 \mathrm{~h}$ & $\begin{array}{l}\mathrm{rScO}_{2} \text { values }>90 \% \text { and a lack of variability over time in } \\
\text { infants with } \mathrm{HIE} \text { during cooling were associated with poor } \\
\text { outcome }\end{array}$ \\
\hline Bale et al. (25) & Observational & $\geq 38$ & 6 & $\begin{array}{l}\text { Feasibility study to assess the } \\
\text { potential of cytochrome c oxidase } \\
\text { monitoring in NE }\end{array}$ & $\begin{array}{l}\text { Broadband } \\
\text { NIRS }\end{array}$ & Frontal bilateral & $\begin{array}{l}\text { Up to } 5 \\
\text { days }\end{array}$ & $\begin{array}{l}\text { Mean values for } \mathrm{HbD} \text { and oxCCO consistently decreased } \\
\text { during desaturation and } \mathrm{HbT} \text { increased. }\end{array}$ \\
\hline Bale et al. (26) & $\begin{array}{l}\text { Prospective } \\
\text { observational }\end{array}$ & $>35$ & 11 & $\begin{array}{l}\text { To investigate the dynamic changes in } \\
\text { cerebral metabolism in response to } \\
\text { systemic changes, as a marker of } \\
\text { injury }\end{array}$ & $\begin{array}{l}\text { Broadband } \\
\text { NIRS }\end{array}$ & Frontal & $\begin{array}{l}3 \mathrm{~h} \text { on day } 3 \\
\text { of } \mathrm{TH}\end{array}$ & $\begin{array}{l}\text { Strong relationship between oxCCO and systemic variables } \\
\text { during } \mathrm{TH} \text { on day } 3 \text { indicated severe injury following } \mathrm{HI}\end{array}$ \\
\hline Bale et al. (27) & $\begin{array}{l}\text { Prospective } \\
\text { observational }\end{array}$ & $>36$ & 50 & $\begin{array}{l}\text { To determine whether broadband } \\
\text { NIRS can distinguish injury severity in } \\
\text { HIE in the first } 4 \text { days after birth }\end{array}$ & $\begin{array}{l}\text { Broadband } \\
\text { NIRS }\end{array}$ & Frontal & Up to day 4 & $\begin{array}{l}\text { A strong relationship between cerebral metabolism } \\
\text { [broadband NIRS-measured cytochrome-c-oxidase (CCO)] } \\
\text { and cerebral oxygenation was associated with unfavorable } \\
\text { outcome during spontaneous desaturation episodes during } \\
\text { TH. }\end{array}$ \\
\hline Bale et al. (28) & Observational & $>36$ & 11 & $\begin{array}{l}\text { To use changes in cerebral } \\
\text { oxygenation and peripheral oxygen } \\
\text { saturation during spontaneous } \\
\text { desaturation for determination of CBF }\end{array}$ & $\begin{array}{l}\text { Broadband } \\
\text { NIRS }\end{array}$ & Frontal & Up to day 4 & $\begin{array}{l}\text { Infants with severe HIE had significantly lower CBF compared } \\
\text { with infants with moderate HIE on the day of birth }\end{array}$ \\
\hline Burton et al. (29) & Observational & $\geq 35$ & 19 & $\begin{array}{l}\text { To assess the relationship between } \\
\text { autoregulation during TH and } \\
\text { neurodevelopmental outcomes at } 2 \\
\text { years of age }\end{array}$ & INVOS 5100 & Forehead & $84 \mathrm{~h}$ & $\begin{array}{l}\text { Children with developmental impairments at } 2 \text { years, had } \\
\text { higher MAPOPT values, spent more time with MABP below } \\
\text { MAPOPT, and had greater MABP deviation below MAPOPT } \\
\text { during rewarming. Greater MABP deviation above MAPOPT } \\
\text { during rewarming was associated with less disability and } \\
\text { higher cognitive scores }\end{array}$ \\
\hline $\begin{array}{l}\text { Campbell et al. } \\
\text { (30) }\end{array}$ & Observational & $>36$ & 27 & $\begin{array}{l}\text { Whether infants with autonomic } \\
\text { dysfunction after HIE have aberrant } \\
\text { physiological responses to care } \\
\text { events }\end{array}$ & NIRO-200NX & $\begin{array}{l}\text { Right and left } \\
\text { frontotemporal }\end{array}$ & $2.58-8 \mathrm{~h}$ & $\begin{array}{l}\text { Infants with depressed heart rate (HR) variability had different } \\
\text { physiological responses [post event changes in cerebral } \\
\text { blood flow }(\mathrm{HbD}) \text { and cerebral blood volume }(\mathrm{HbT}) \text { ] compared } \\
\text { to infants with intact HR variability }\end{array}$ \\
\hline Chalak et al. (31) & Observational & $\geq 36$ & 10 & $\begin{array}{l}\text { To develop an approach to assess } \\
\text { cerebral hemodynamics across } \\
\text { multiple time scales during first } 72 \mathrm{~h} \\
\text { of life }\end{array}$ & $\begin{array}{l}\text { INVOS } \\
4100-5100\end{array}$ & $\begin{array}{l}\text { left } \\
\text { frontoparietal }\end{array}$ & $72 \mathrm{~h}$ & $\begin{array}{l}\text { multiple-timescale correlations between oscillations in MAP } \\
\text { and } \mathrm{SctO}_{2} \text { in the first } 72 \mathrm{hrs,} \text { indicating impairment of cerebral } \\
\text { hemodynamics }\end{array}$ \\
\hline
\end{tabular}

or 
TABLE 2 | Continued

\begin{tabular}{|c|c|c|c|c|c|c|c|c|}
\hline $\begin{array}{l}\text { First author, } \\
\text { Year (Ref.) }\end{array}$ & $\begin{array}{l}\text { Study } \\
\text { design }\end{array}$ & $\begin{array}{l}\text { Gestation } \\
\text { (weeks) }\end{array}$ & $\begin{array}{l}\text { No of } \\
\text { subjects }\end{array}$ & Study aim & $\begin{array}{l}\text { NIRS device, } \\
\text { sensor }\end{array}$ & $\begin{array}{l}\text { Optode } \\
\text { placement on } \\
\text { head }\end{array}$ & $\begin{array}{l}\text { Duration } \\
\text { of study }\end{array}$ & Result \\
\hline Chalak et al. (32) & Observational & $\geq 36$ & 10 & $\begin{array}{l}\text { To quantify neurovascular coupling } \\
\text { (NVC) using wavelet analysis of the } \\
\text { dynamic coherence between aEEG } \\
\text { and } \mathrm{SctO}_{2} \text { in } \mathrm{NE}\end{array}$ & $\begin{array}{l}\text { INVOS } \\
4100-5100\end{array}$ & $\begin{array}{l}\text { Bilateral parietal } \\
\text { area }\end{array}$ & $60 \pm 6 h$ & $\begin{array}{l}\text { High coherence, intact NVC between the oscillations of } \\
\mathrm{SctO}_{2} \text { and aEEG in the frequency range of } 0.00025-0.001 \mathrm{~Hz} \\
\text { in the non-encephalopathic newborns. NVC coherence was } \\
\text { significantly decreased in encephalopathic newborns who } \\
\text { were cooled vs. non- encephalopathic controls and was } \\
\text { significantly lower in those with abnormal } 2 \text { year outcomes } \\
\text { relative to those with normal outcomes }\end{array}$ \\
\hline Chen et al. (33) & Observational & $>35.7$ & 44 & $\begin{array}{l}\text { To evaluate the evoked CBO } \\
\text { response to neuronal activation in } \\
\text { newborns with HIE and compare with } \\
\text { the response in healthy infants }\end{array}$ & NIRO 500 & Forehead & $\begin{array}{l}\text { Between } \\
\text { day } 1-3\end{array}$ & $\begin{array}{l}\text { Infants with } \mathrm{HIE} \text { have decreased } \mathrm{rCBF} \text { in the frontal lobes } \\
\text { during auditory stimulation, (decrease of } \mathrm{HbO}_{2} \text { and } \mathrm{HbT} \text { ) } \\
\text { compared to normal infants }\end{array}$ \\
\hline Chock et al. (34) & $\begin{array}{l}\text { Retrospective } \\
\text { chart review }\end{array}$ & $\geq 36$ & 38 & $\begin{array}{l}\text { To review cerebral and renal tissue } \\
\text { saturation during } \mathrm{TH}\end{array}$ & INVOS 5100C & $\begin{array}{l}\text { Lateral } \\
\text { forehead }\end{array}$ & $110 \mathrm{~h}$ & $\begin{array}{l}\text { Renal tissue saturation was lower than cerebral tissue } \\
\text { saturation during } \mathrm{TH}\end{array}$ \\
\hline $\begin{array}{l}\text { Dehaes et al. } \\
\text { (35) }\end{array}$ & Observational & $\geq 36$ & 27 & $\begin{array}{l}\text { To assess cerebral hemodynamics } \\
\text { and oxygen metabolism during and } \\
\text { after TH }\end{array}$ & $\begin{array}{l}\text { Hybrid } \\
\text { FDNIRS-DCS } \\
\text { system }\end{array}$ & $\begin{array}{l}\text { Left, middle, } \\
\text { and right frontal }\end{array}$ & $\begin{array}{l}10-16 \text { sec } \\
3 \text { times/ } \\
\text { location } \\
\text { during } \mathrm{TH} \text {, } \\
\text { rewarming, } \\
\text { and } \\
\text { post-TH }\end{array}$ & $\begin{array}{l}\mathrm{CMRO}_{2 \mathrm{i}} \text { and } \mathrm{CBF} \text { lower in neonates with } \mathrm{HIE} \text { during } \mathrm{TH} \\
\text { compared with post }-\mathrm{TH} \text { and controls }\end{array}$ \\
\hline $\begin{array}{l}\text { Forman et al. } \\
\text { (36) }\end{array}$ & $\begin{array}{l}\text { Prospective } \\
\text { observational }\end{array}$ & $>35$ & 20 & $\begin{array}{l}\text { To assess the feasibility and reliability } \\
\text { cerebral perfusion monitoring in NE }\end{array}$ & $\begin{array}{l}\text { INVOS, } \\
\text { neonatal } \\
\text { sensors }\end{array}$ & $\begin{array}{l}\text { Center of the } \\
\text { forehead }\end{array}$ & $84 \mathrm{~h}$ & $\begin{array}{l}\mathrm{SctO}_{2} \text { increased over first } 30 \mathrm{~h} \text { of } \mathrm{TH} \text { and stayed high for the } \\
\text { remainder of the study }\end{array}$ \\
\hline $\begin{array}{l}\text { Gagnon and } \\
\text { Wintermark (37) }\end{array}$ & Case series & $>38$ & 3 & $\begin{array}{l}\text { To examine the impact of PPHN on } \\
\text { cerebral oxygenation in infants on } \mathrm{TH} \\
\text { after } \mathrm{HIE}\end{array}$ & FORE-SIGHT & $\begin{array}{l}\text { Forehead } \\
\text { (bilateral) }\end{array}$ & $86 \mathrm{~h}$ & $\begin{array}{l}\text { Periods of pulmonary hypertensive crisis were associated } \\
\text { with significant drop in cerebral saturation, indicating that } \\
\text { PPHN can independently cause further injury }\end{array}$ \\
\hline Goeral et al. (38) & $\begin{array}{l}\text { Prospective } \\
\text { observational }\end{array}$ & $>36$ & 32 & $\begin{array}{l}\text { To assess the predictive values of } \\
\text { aEEG and NIRS parameters and the } \\
\text { respective cut-off values regarding } \\
\text { short-term outcomes in HIE }\end{array}$ & INVOS 5100C & Frontoparietal & $102 \mathrm{~h}$ & $\begin{array}{l}\text { No significant differences in NIRS values were observed } \\
\text { between groups (normal and abnormal MRI). Combined } \\
\text { score of BP, aEEG and NIRS increased the accuracy of early } \\
\text { outcome prediction }\end{array}$ \\
\hline $\begin{array}{l}\text { Govindan et al. } \\
\text { (39) }\end{array}$ & Observational & n.r. & 4 & $\begin{array}{l}\text { To identify the efficacy of a modified } \\
\text { approach to quantify the pressure } \\
\text { passivity }\end{array}$ & NIRO 200 & $\begin{array}{l}\text { Bilateral } \\
\text { fronto-temporal } \\
\text { areas }\end{array}$ & n.r. & $\begin{array}{l}\text { A modified coherence estimation approach over every } 30 \mathrm{~s} \\
\text { epochs identified better the association between } \mathrm{HbD} \text { and } \\
\text { MABP (pressure passivity index). }\end{array}$ \\
\hline $\begin{array}{l}\text { Govindan et al. } \\
(40)\end{array}$ & Observational & $\geq 38$ & 4 & $\begin{array}{l}\text { To review the efficacy of a novel } \\
\text { method to quantify neuro-vascular } \\
\text { coupling (NVC) using NIRS and EEG }\end{array}$ & NIRO 200 & $\begin{array}{l}\text { Bilateral } \\
\text { fronto-temporal } \\
\text { areas }\end{array}$ & n.r. & $\begin{array}{l}\text { Two infants who survived, revealed the emergence of NVC } \\
\text { during TH. Other } 2 \text { infants who did not survive, lacked this } \\
\text { feature. }\end{array}$ \\
\hline Grant et al. (41) & Observational & $\geq 33$ & 43 & $\begin{array}{l}\text { Whether } \mathrm{StO} 2, \mathrm{CBV} \text {, and } \mathrm{rCMRO}_{2} \\
\text { have the potential to distinguish } \\
\text { between neonates with brain injury } \\
\text { (HIE and other etiologies) and healthy } \\
\text { controls }\end{array}$ & FDNIRS & $\begin{array}{l}5 \pm 3 \text { locations. } \\
\text { Primary location } \\
\text {-forehead, also } \\
\text { temporal and } \\
\text { parietal }\end{array}$ & n.r. & $\begin{array}{l}\text { No significant difference in } \mathrm{StO}_{2} \text { between brain-injured and } \\
\text { normal neonates. However, } \mathrm{CBV} \text { and estimates of } \mathrm{rCMRO}_{2} \\
\text { were significantly increased in the brain injured group } \\
\text { compared with all other clinical groups }\end{array}$ \\
\hline
\end{tabular}


TABLE 2 | Continued

\begin{tabular}{|c|c|c|c|c|c|c|c|c|}
\hline $\begin{array}{l}\text { First author, } \\
\text { Year (Ref.) }\end{array}$ & $\begin{array}{l}\text { Study } \\
\text { design }\end{array}$ & $\begin{array}{l}\text { Gestation } \\
\text { (weeks) }\end{array}$ & $\begin{array}{l}\text { No of } \\
\text { subjects }\end{array}$ & Study aim & $\begin{array}{l}\text { NIRS device, } \\
\text { sensor }\end{array}$ & $\begin{array}{l}\text { Optode } \\
\text { placement on } \\
\text { head }\end{array}$ & $\begin{array}{l}\text { Duration } \\
\text { of study }\end{array}$ & Result \\
\hline $\begin{array}{l}\text { Gucuyener et al. } \\
\text { (42) }\end{array}$ & Observational & $\geq 36$ & 8 & $\begin{array}{l}\text { Investigate the correlations between } \\
\mathrm{aEEG} \text { and NIRS monitoring and } \\
\text { outcome following HIE }\end{array}$ & NIRO 200 & Parietal & $\begin{array}{l}30 \text { min each } \\
\text { before } \\
\text { cooling, at } \\
34^{\circ} \mathrm{C} \text { during } \\
\mathrm{TH} \text { and } \\
\text { after } \\
\text { rewarming }\end{array}$ & $\begin{array}{l}\text { Detection of context-sensitive changes in TOI and FTOE can } \\
\text { be helpful especially while monitoring the effects of a therapy, } \\
\text { in conjunction with other cerebral trend monitors }\end{array}$ \\
\hline $\begin{array}{l}\text { Howlett et al. } \\
\text { (43) }\end{array}$ & Observational & $>37$ & 24 & $\begin{array}{l}\text { To describe the relationship between } \\
\text { autoregulation during TH and brain } \\
\text { injury on MRI after HIE }\end{array}$ & $\begin{array}{l}\text { INVOS, } \\
\text { Neonatal } \\
\text { sensor }\end{array}$ & Forehead & $84 \mathrm{~h}$ & $\begin{array}{l}\text { Optimal MABP identified using HVx (running correlation } \\
\text { between } \mathrm{HBT} \text { and MAP). Infants with evidence of brain injury } \\
\text { on MRI spent longer time below MAPOPT during rewarming } \\
\text { than neonates with no or mild injury. Neonates with } \\
\text { moderate/severe injury on MRI had greater MAP deviation } \\
\text { below MAPOPT during rewarming than neonates without injury }\end{array}$ \\
\hline Huang et al. (44) & Observational & $\geq 37$ & 41 & $\begin{array}{l}\text { To find out the clinically useful } \\
\text { parameters for the assessment of HIE } \\
\text { using NIRS }\end{array}$ & TSNIR-3 & n.r. & n.r. & $\begin{array}{l}\mathrm{rSO}_{2} \text { in quiet condition and } \mathrm{rSO} 2, \mathrm{HbO}_{2} \text { and } \mathrm{Hb} \text { during the } \\
\text { inhalation of oxygen may be helpful for } \mathrm{HIE} \text { infants. } \mathrm{rSO} 2 \text { for } \\
\text { the healthy group increased rapidly, with the increase } 7 \pm \\
2.3 \% \text {, compared to } 3 \pm 1.5 \% \text { in } \mathrm{HIE} \text { infants }\end{array}$ \\
\hline Jain et al. (45) & $\begin{array}{l}\text { Prospective } \\
\text { observational }\end{array}$ & $>36$ & 21 & To examine the value of $\mathrm{CrSO}_{2}$ & INVOS & Midfrontal & $48 \mathrm{~h}$ & $\begin{array}{l}\text { Higher absolute } \mathrm{CrSO}_{2} \text { values during } \mathrm{TH} \text { correlates with } \\
\text { subcortical injury on } \mathrm{MRI} \text { and poor neurodevelopmental } \\
\text { outcome }\end{array}$ \\
\hline $\begin{array}{l}\text { Kovacsova et al. } \\
(46)\end{array}$ & Observational & $>36$ & 55 & $\begin{array}{l}\text { To investigate the SRS algorithm } \\
\text { using a multi-distance broadband } \\
\text { NIRS device to derive tissue } \\
\text { saturation }\end{array}$ & $\begin{array}{l}\text { Broadband } \\
\text { NIRS }\end{array}$ & Frontal & $14 \mathrm{~h}$ & $\begin{array}{l}\text { A broadband NIRS multi-distance device can provide } \\
\text { additional information to improve the robustness of the SRS } \\
\text { estimation of cerebral tissue saturation }\end{array}$ \\
\hline Lee et al. (47) & $\begin{array}{l}\text { Prospective } \\
\text { observational }\end{array}$ & & 64 & $\begin{array}{l}\text { To examine whether optimizing } \\
\text { cerebral autoregulation is associated } \\
\text { with decreased brain injury }\end{array}$ & INVOS 5100 & $\begin{array}{l}\text { Bilateral } \\
\text { forehead }\end{array}$ & $90 \mathrm{~h}$ & $\begin{array}{l}\text { Blood pressure deviation from the optimal vasoreactivity was } \\
\text { associated with evidence of brain injury on MRI, independent } \\
\text { of initial birth asphyxia }\end{array}$ \\
\hline $\begin{array}{l}\text { Lemmers et al. } \\
\text { (48) }\end{array}$ & Observational & $\geq 36$ & 39 & $\begin{array}{l}\text { To re-evaluate the early predictive } \\
\text { value of } \mathrm{rScO}_{2}, \mathrm{CFTOE} \text { and } \mathrm{aEEG} \\
\text { background pattern for outcome }\end{array}$ & $\begin{array}{l}\text { INVOS } \\
4100-5100, \\
\text { with adult } \\
\text { sensor }\end{array}$ & Frontoparietal & $84 \mathrm{~h}$ & $\begin{array}{l}\text { Higher } \mathrm{rScO}_{2} \text { values and lower aEEG background pattern } \\
\text { scores in neonates with adverse neurodevelopmental } \\
\text { outcome }\end{array}$ \\
\hline $\begin{array}{l}\text { Massaro et al. } \\
\text { (49) }\end{array}$ & $\begin{array}{l}\text { Prospective } \\
\text { observational }\end{array}$ & $>36$ & 10 & $\begin{array}{l}\text { To assess cerebral perfusion and } \\
\text { oxygenation differences after } \mathrm{HIE}\end{array}$ & FORE-SIGHT & n.r. & $84 \mathrm{~h}$ & $\begin{array}{l}\text { Cerebral FTOE values were significantly reduced after } \\
\text { rewarming in infants with evidence of injury on MR imaging }\end{array}$ \\
\hline $\begin{array}{l}\text { Massaro et al. } \\
\text { (50) }\end{array}$ & Observational & $\geq 35$ & 36 & $\begin{array}{l}\text { To investigate if the duration and } \\
\text { magnitude of the pressure passivity } \\
\text { during } \mathrm{TH} \text { were related to outcome }\end{array}$ & NIRO 200 & $\begin{array}{l}\text { Fronto- } \\
\text { temporal }\end{array}$ & $84 \mathrm{~h}$ & $\begin{array}{l}\text { Higher PPI in both hemispheres and high gain on right } \\
\text { hemisphere were associated with poor outcome }\end{array}$ \\
\hline Meek et al. (2) & Observational & $\geq 36$ & 27 & $\begin{array}{l}\text { To measure changes in cerebral } \\
\text { hemodynamics during the first } 24 \text { hrs } \\
\text { of life after perinatal asphyxia, and } \\
\text { relate them to outcome }\end{array}$ & $\begin{array}{l}\text { NIRO1000 or } \\
\text { NIRO500 }\end{array}$ & n.r. & $\begin{array}{l}1-4 \\
\text { occasions } \\
\text { between } 2 \\
\text { and } 72 \mathrm{~h} \text { of } \\
\text { age }\end{array}$ & $\begin{array}{l}\text { increase in CBV on the 1st day of life is a sensitive predictor } \\
\text { of adverse outcome. A reduction in CBVR is almost } \\
\text { universally seen following asphyxia, but is not significantly } \\
\text { correlated with severity of adverse outcome }\end{array}$ \\
\hline
\end{tabular}


TABLE 2 | Continued

\begin{tabular}{|c|c|c|c|c|c|c|c|c|}
\hline $\begin{array}{l}\text { First author, } \\
\text { Year (Ref.) }\end{array}$ & $\begin{array}{l}\text { Study } \\
\text { design }\end{array}$ & $\begin{array}{l}\text { Gestation } \\
\text { (weeks) }\end{array}$ & $\begin{array}{l}\text { No of } \\
\text { subjects }\end{array}$ & Study aim & $\begin{array}{l}\text { NIRS device, } \\
\text { sensor }\end{array}$ & $\begin{array}{l}\text { Optode } \\
\text { placement on } \\
\text { head }\end{array}$ & $\begin{array}{l}\text { Duration } \\
\text { of study }\end{array}$ & Result \\
\hline Mitra et al. (51) & $\begin{array}{l}\text { Prospective } \\
\text { observational }\end{array}$ & $\geq 35$ & 14 & $\begin{array}{l}\text { To assess the cerebral metabolic and } \\
\text { hemodynamic changes during the } \\
\text { rewarming period after } \mathrm{TH}\end{array}$ & $\begin{array}{l}\text { Broadband } \\
\text { NIRS }\end{array}$ & Frontal & $14 \mathrm{~h}$ & $\begin{array}{l}\text { The relationship between mitochondrial metabolism and } \\
\text { oxygenation became impaired with rising Lac/NAA. } \\
\text { Cardiovascular parameters remained stable during } \\
\text { rewarming. }\end{array}$ \\
\hline Mitra et al. (52) & $\begin{array}{l}\text { Prospective } \\
\text { observational }\end{array}$ & $>34$ & 23 & $\begin{array}{l}\text { To investigate the effects of } \\
\text { disturbances in brain metabolism } \\
\text { following HIE on outcome, using a } \\
\text { wavelet based metabolic reactivity } \\
\text { index between oxCCO and MABP }\end{array}$ & $\begin{array}{l}\text { Broadband } \\
\text { NIRS }\end{array}$ & Frontal & $1 \mathrm{~h}$ & $\begin{array}{l}\text { Pressure passive changes in brain metabolism were } \\
\text { associated with injury severity and outcome following HIE. } \\
\text { oxCCO-MABP semblance as a metabolic reactivity index } \\
\text { correlated with MRS derived Lac/NAA. It also differed among } \\
\text { groups of mild to moderate and severe injury based on MRI } \\
\text { score and neuro-developmental outcome at } 1 \text { yr of age. }\end{array}$ \\
\hline Mitra et al. (53) & $\begin{array}{l}\text { Prospective } \\
\text { observational }\end{array}$ & $>36$ & 14 & $\begin{array}{l}\text { To assess the changes in brain } \\
\text { hemodynamics and metabolism } \\
\text { following HIE in relation to initial } \\
\text { degree on injury on EEG }\end{array}$ & $\begin{array}{l}\text { Broadband } \\
\text { NIRS }\end{array}$ & Frontal & $12.5 \mathrm{~h}$ & $\begin{array}{l}\text { Significant difference noted in derangement of brain } \\
\text { oxygenation and metabolism between infants with mild and } \\
\text { moderate to severe EEG abnormality }\end{array}$ \\
\hline $\begin{array}{l}\text { Nakamura et al. } \\
\text { (54) }\end{array}$ & Observational & $>35$ & 11 & $\begin{array}{l}\text { To find the influence of CBV and } \\
\mathrm{ScO}_{2} \text { on clinical outcome }\end{array}$ & TRS-10 & Parietal & $72 \mathrm{~h}$ & $\begin{array}{l}\text { Early postnatal } \mathrm{CBV} \text { and } \mathrm{ScO}_{2} \text { elevations were predictive of a } \\
\text { poor outcome based on } \mathrm{MRI} \text { injury }\end{array}$ \\
\hline Niezen et al. (55) & $\begin{array}{l}\text { Retrospective } \\
\text { observational } \\
\text { study }\end{array}$ & $\geq 37$ & 39 & $\begin{array}{l}\text { To determine the predictive value of } \\
\text { aEEG and NIRS alone, and in } \\
\text { combination, during the first } 4 \text { days } \\
\text { after HIE }\end{array}$ & INVOS 5100C & $\begin{array}{l}\text { left or right } \\
\text { frontoparietal }\end{array}$ & $96 \mathrm{~h}$ & $\begin{array}{l}\text { After } 48 \mathrm{~h} \text { of } \mathrm{TH} \text {, a higher } \mathrm{rcSO}_{2} \text { was associated with a } \\
\text { severely abnormal outcome }\end{array}$ \\
\hline Peng et al. (56) & Observational & $>=36$ & 18 & $\begin{array}{l}\text { To assess whether NIRS Identifies the } \\
\text { newborns during TH, who later } \\
\text { develop brain injury }\end{array}$ & FORE-SIGHT & Forehead & $79 \mathrm{~h}$ & $\begin{array}{l}\text { rSO2 was consistently higher in newborns who developed } \\
\text { brain injury on MRI and was significantly higher on day } 1 \\
\text { compared to infants who did not develop injury on brain MRI. }\end{array}$ \\
\hline $\begin{array}{l}\text { Shellhaas et al. } \\
\text { (57) }\end{array}$ & Observational & $\geq 37$ & 21 & $\begin{array}{l}\text { To evaluate the utility of aEEG and } \\
\mathrm{rSO}_{2} \text { for short-term outcome }\end{array}$ & INVOS 5100C & $\begin{array}{l}\text { bilateral parietal } \\
\text { regions, also } \\
\text { one sensor over } \\
\text { thigh }\end{array}$ & $90 \mathrm{~h}$ & $\begin{array}{l}\text { During day } 3 \text { of cooling and during rewarming, loss of } \\
\text { physiologic variability (by systemic NIRS) was the best } \\
\text { predictor of poor short-term outcome. Cerebral rSO2 } \\
\text { variability was independent from short-term outcome }\end{array}$ \\
\hline $\begin{array}{l}\text { Shellhaas et al. } \\
\text { (58) }\end{array}$ & Observational & $\geq 35$ & 4 & $\begin{array}{l}\text { To evaluate the variability of cerebral } \\
\text { oxygen metabolism in sleep-wake } \\
\text { states among sick neonates }\end{array}$ & INVOS 5100C & $\begin{array}{l}\text { bilateral } \\
\text { parietal- } \\
\text { occipital } \\
\text { regions }\end{array}$ & $11.7 \mathrm{~h}$ & $\begin{array}{l}\text { Cerebral oxygenation }\left(\mathrm{sSO}_{2}\right) \text { and FTOE significantly differ } \\
\text { between wakefullness and sleep stages }\end{array}$ \\
\hline $\begin{array}{l}\text { Shellhaas et al. } \\
\text { (59) }\end{array}$ & Observational & $\begin{array}{l}\text { "term } \\
\text { neonates" }\end{array}$ & 18 & $\begin{array}{l}\text { To identify systemic and cerebral risk } \\
\text { factors for adverse long-term } \\
\text { neuro-developmental outcome } \\
\text { following HIE }\end{array}$ & INVOS 5100C & $\begin{array}{l}\text { Bilateral parietal } \\
\text { regions, } \\
\text { neonatal } \\
\text { sensors }\end{array}$ & $72 \mathrm{~h}$ & $\begin{array}{l}\text { Mean cerebral } \mathrm{rSO}_{2} \text { was not different between those with } \\
\text { favorable vs. adverse } 18 \text {-months outcomes, but those with } \\
\text { favorable outcomes had higher systemic } \mathrm{rSO}_{2} \text { variability } \\
\text { during hours } 48-72 \text { of cooling }\end{array}$ \\
\hline Tax et al. (60) & Observational & $>34$ & 38 & $\begin{array}{l}\text { To investigate peripheral oxygenation } \\
\text { and perfusion in the first } 48 \mathrm{~h} \text { after } \\
\text { perinatal asphyxia }\end{array}$ & NIRO 300 & Left calf & n.r. & $\begin{array}{l}\text { Peripheral oxygenation and perfusion are compromised with } \\
\text { worsening degree of acidosis on cord blood gas }\end{array}$ \\
\hline
\end{tabular}




\begin{tabular}{|c|c|c|c|c|c|c|c|c|}
\hline $\begin{array}{l}\text { First author, } \\
\text { Year (Ref.) }\end{array}$ & $\begin{array}{l}\text { Study } \\
\text { design }\end{array}$ & $\begin{array}{l}\text { Gestation } \\
\text { (weeks) }\end{array}$ & $\begin{array}{l}\text { No of } \\
\text { subjects }\end{array}$ & Study aim & $\begin{array}{l}\text { NIRS device, } \\
\text { sensor }\end{array}$ & $\begin{array}{l}\text { Optode } \\
\text { placement on } \\
\text { head }\end{array}$ & $\begin{array}{l}\text { Duration } \\
\text { of study }\end{array}$ & Result \\
\hline Tekes et al. (61) & Observational & $\geq 35$ & 27 & $\begin{array}{l}\text { To assess whether lower ADC values } \\
\text { on MRI would correlate with worse } \\
\text { autoregulatory status measured by } \\
\text { NIRS }\end{array}$ & INVOS & $\begin{array}{l}\text { Forehead } \\
\text { bilateral }\end{array}$ & n.r. & $\begin{array}{l}\text { Lower ADC scalars in the PCS, PLIC and PP correlated with } \\
\text { blood pressure deviation below MAPOPT during hypothermia } \\
\text { and rewarming }\end{array}$ \\
\hline Tian et al. (62) & Observational & $\geq 36$ & 9 & $\begin{array}{l}\text { Quantitative evaluation of cerebral } \\
\text { autoregulation }\end{array}$ & $\begin{array}{l}\text { INVOS } \\
4100-5100 \\
\text { neonatal } \\
\text { sensor }\end{array}$ & Frontoparietal & $72 \mathrm{~h}$ & $\begin{array}{l}\text { Cerebral autoregulation was time-scale -dependant. Both in } \\
\text { phase and anti-phase coherence were related to worse } \\
\text { outcome }\end{array}$ \\
\hline Toet et al. (15) & Observational & $>37$ & 18 & $\begin{array}{l}\text { To determine the value of } \mathrm{rSO}_{2}, \mathrm{FTOE} \\
\text { measured by NIRS, and aEEG in } \\
\text { relation to neuro-developmental } \\
\text { outcome }\end{array}$ & INVOS 4100 & Left parietal & $48 \mathrm{~h}$ & $\begin{array}{l}\mathrm{rSO}_{2} \text { values remained normal and stable in infants with a } \\
\text { normal outcome with values between } 50 \text { and } 70 \% 30,33 \text { but } \\
\text { increased to supranormal values after } 24 \mathrm{~h} \text { in the infants with } \\
\text { an adverse outcome. From } 24 \mathrm{~h} \text { onward, the values of } \mathrm{rSO}_{2} \\
\text { of the infants with an adverse outcome were significantly } \\
\text { higher as compared with those with a favorable outcome }\end{array}$ \\
\hline $\begin{array}{l}\text { Van Bel et al. } \\
\text { (18) }\end{array}$ & Observational & $>35$ & 31 & $\begin{array}{l}\text { To investigate whether cerebral } \\
\text { perfusion and metabolism drops } \\
\text { following hypoxia }\end{array}$ & Radiometer & $\begin{array}{l}\text { Source on ant. } \\
\text { fontanel, } \\
\text { detector on } \\
\text { Fronto-parietal }\end{array}$ & $4-6 h$ & $\begin{array}{l}\mathrm{CBV}, \mathrm{HbO}, \mathrm{HbR} \text {, and } \mathrm{Cytaa}_{3} \text { decreased in the first } 12 \mathrm{hs} \text { of } \\
\text { life in severely asphyxiated neonates who subsequently } \\
\text { developed neurologic abnormalities }\end{array}$ \\
\hline $\begin{array}{l}\text { Wintermark et al. } \\
\text { (63) }\end{array}$ & Observational & $\geq 36$ & 7 & $\begin{array}{l}\text { To determine the correlation between } \\
\text { measurements of brain perfusion by } \\
\text { NIRS and by MRI }\end{array}$ & $\begin{array}{l}\text { FORE-SIGHT } \\
\text { Cerebral } \\
\text { Oximeter }\end{array}$ & Forehead & $84 \mathrm{~h}$ & $\begin{array}{l}\mathrm{SctO}_{2} \text { and } \mathrm{CBF} \text { increase from days } 1 \text { to } 2 \text { in all, despite } \mathrm{TH} \text {. } \\
\mathrm{SctO}_{2} \text { and } \mathrm{CBF} \text { are highly correlated in newborns with severe } \\
\text { encephalopathy. Newborns with severe encephalopathy have } \\
\text { lower } \mathrm{CBF} \text { than newborns with moderate encephalopathy. } \\
\text { Newborns developing brain } \mathrm{HI} \text { injury have higher } \mathrm{SctO}_{2} \text { than } \\
\text { newborns not developing brain injury }\end{array}$ \\
\hline Wu et al. (64) & $\begin{array}{l}\text { Retrospective } \\
\text { cohort study }\end{array}$ & $\geq 36$ & 20 & $\begin{array}{l}\text { To review the cerebral hemodynamic } \\
\text { response during rewarming following } \\
\text { TH }\end{array}$ & INVOS 5100C & Frontal region & $14 \mathrm{~h}$ & $\begin{array}{l}\mathrm{CrSO}_{2} \text { and cerebral FTOE remained unchanged during } \\
\text { rewarming }\end{array}$ \\
\hline $\begin{array}{l}\text { Zaramella et al. } \\
\text { (65) }\end{array}$ & $\begin{array}{l}\text { Case control } \\
\text { study }\end{array}$ & $\geq 36$ & 22 & $\begin{array}{l}\text { To assess the diagnostic and } \\
\text { prognostic value of } \mathrm{TOI} \text { and } \Delta \mathrm{CBV} \text { in } \\
\mathrm{HIE}\end{array}$ & NIRO 300 & $\begin{array}{l}\text { Fronto- } \\
\text { temporal }\end{array}$ & $\begin{array}{l}\text { Duration } \\
\text { n.r., study } \\
\text { on day } 1\end{array}$ & $\begin{array}{l}\text { Increased TOI on day } 1 \text { suggested abnormal outcome at } 1 \\
\text { year of age }\end{array}$ \\
\hline
\end{tabular}

ADC, Apparent diffusion coefficient; aEEG, Amplitude integrated electroencephalogram; HIE, Hypoxic-ischemic encephalopathy; CBO, Cerebral blood oxygenation; CBV, Cerebral blood volume; CCVR, Cerebral blood volume response; $\mathrm{CrSO}_{2}$, Cerebral regional oxygen saturation; Cytaa3, Cytochrome oxidase; DCS, Diffusion correlation spectroscopy; EEG, Electroencephalography; FDNIRS, Frequency-domain near-infrared spectroscopy; FTOE, Fractional tissue oxygen extraction; HbO, Oxy-hemoglobin; HbR, Deoxy-hemoglobin; MABP, Mean arterial blood pressure; MRI, Magnetic resonance imaging; MRS, Magnetic resonance spectroscopy; NE, Neonatal encephalopathy; NIRS, Near Infrared spectroscopy; NVC, Neurovascular coupling; oxCCO, Oxidation state of cytochrome c oxidase; PCS, Posterior centrum semiovale; PLIC, Posterior limb of internal capsule; PP, Putamen and globus pallidus; rCMRO, Relative cerebral metabolic rate of oxygen consumption; $\mathrm{rSO}_{2}$, Regional oxygen saturation; $\mathrm{rSCO}_{2}$, Regional cerebral tissue oxygen saturation; $\mathrm{SctO}_{2}$, Regional cerebral tissue oxygen saturation; $\mathrm{StO}{ }_{2}$, Cerebral tissue oxygenation; $\mathrm{TH}$, Therapeutic hypothermia; TOI, Tissue oxygenation index; TH, Therapeutic hypothermia; THI, Total hemoglobin index. 


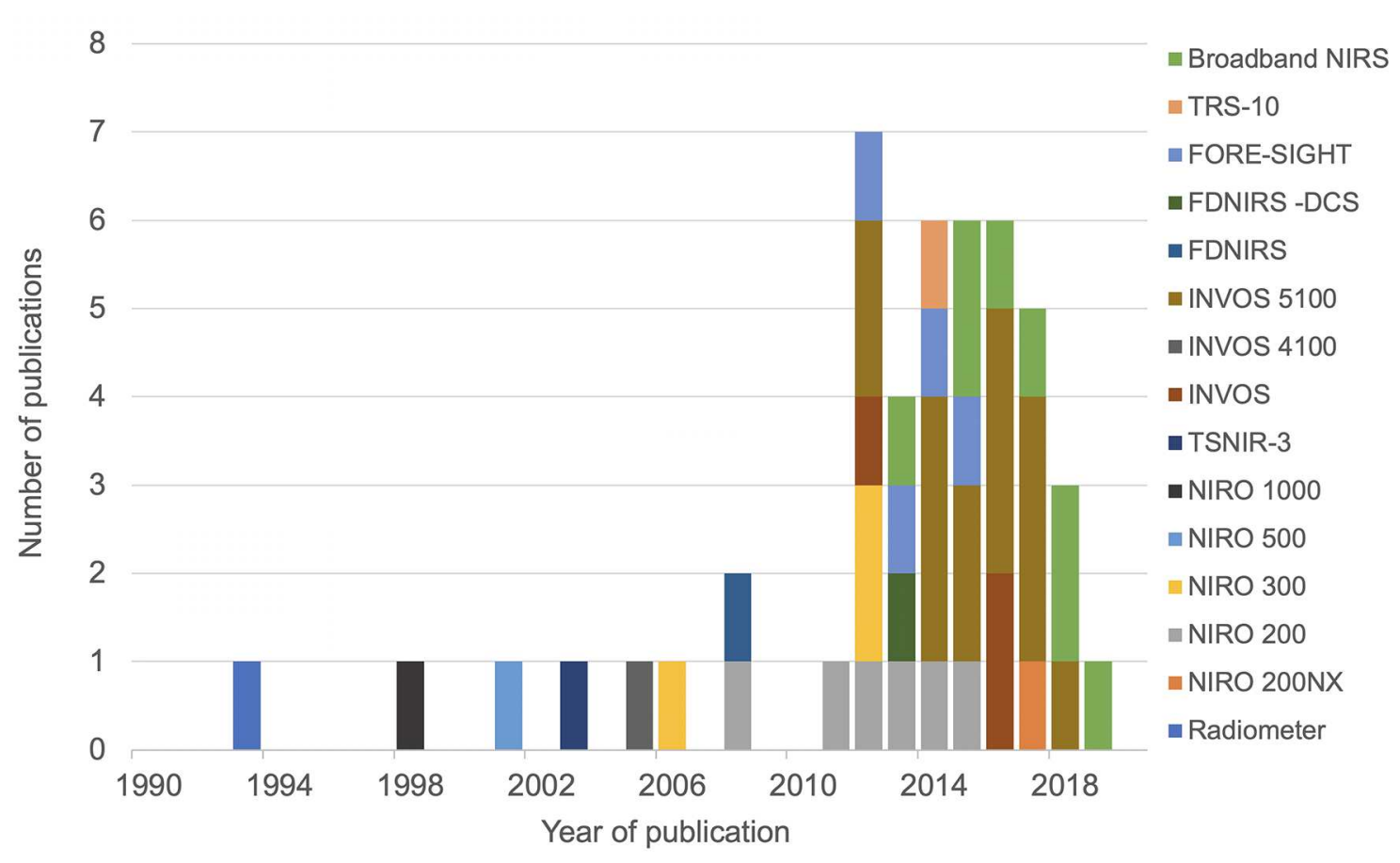

FIGURE 2 | Different NIRS devices used in the studies with their year of publication.

and the transmitted light attenuation and the frequency phase shift are measured. Observations of phase shift relate to tissue scattering, so FD-NIRS systems can derive absolute chromophore concentrations by decoupling absorption from scattering. This gives FD-NIRS a theoretical advantage of a more consistent quantitative measurement which can be important for cerebral NIRS.

The most complex NIRS mode, time domain NIRS (TDNIRS) uses ultrashort pulses of light and measures the time of flight through the tissue with a photon counting device. This enables quantification of scattering and chromophore concentrations absolutely. An additional advantage of time resolved NIRS is the ability to gate the signal to obtain depth resolution. The disadvantages of this technology are the large instrument size and higher cost, although technological advances make up for these drawbacks (67). Both FD-NIRS and TD-NIRS systems appear to have superior depth sensitivity compared to CW-NIRS system (68).

The most common use of NIRS in the neonatal intensive care is a variation on CW-NIRS or FD-NIRS called cerebral oximetry, which allows the quantification of the oxygen saturation within tissue as a percentage using multi-distance approaches. These enable the recovery of scaled absolute measurements using a variety of different techniques (most commercial methods are not published). The NIRO series brain oximeter devices from Hamamatsu implements the spatially resolved spectroscopy (SRS) algorithm with their multi-distance measurements $(69,70)$. The multi-distance designs are less sensitive to changes in the extracerebral layers, giving more brain-specific measurements
(71). Cerebral oxygenation represents the combined oxygen saturation of the arterial and venous vascular compartments, weighted by their volume (ratio of arterial and venous vessels in cerebral tissue is $\sim 25: 75 \%$ ). The simplicity of the reading as an absolute number, small size and low weight of the instrument as well as the high sampling rate makes it ideal for bedside monitoring.

Most commercially available NIRS instruments only measure brain tissue light attenuation at 2-4 wavelengths to resolve hemoglobin oxygenation. However, broadband NIRS devices measure brain tissue light attenuation over a wide range of NIR wavelengths, allowing enhanced spectroscopic information and the possibility to resolve multiple chromophores. Broadband NIRS systems are particularly useful for monitoring changes in CCO (53) together with tissue saturation $(46,72)$. Due to the relatively low concentration of CCO in vivo, the selection of the specific wavelengths and number of wavelengths becomes an important factor for monitoring CCO. Broadband NIRS devices are able to accurately quantify changes in the oxidation state of CCO (oxCCO) by using over 100 wavelengths to improve the optical signal and extract the relatively low concentration changes (19).

DCS measures the microvascular blood flow in the biological tissue. It uses a NIR laser to measure temporal fluctuations in the detected laser intensity which are directly proportional to the speed of scatterers (mainly red blood cells) within the tissue. DCS has been used in combination with a multidistance FDNIRS system to measure an index of the cerebral metabolic rate of oxygen $\left(\mathrm{CMRO}_{2}\right)(35)$. 


\section{MONITORING CEREBRAL OXYGENATION}

Thirty-five studies used cerebral oximetry measurements to describe changes in cerebral tissue oxygen saturation. Different oximetry terminologies have been described in Table 2. Seven studies have also used hemoglobin difference $(\mathrm{HbD})$ as a marker of tissue oxygenation. Although cerebral oximetry presents an absolute value, $\mathrm{HbD}$ is measured as a change in concentration $(27,52)$.

Studies conducted continuously over the period of TH and rewarming revealed a difference in cerebral oxygenation between the groups of infants with good and poor outcome $(56,61)$. Cerebral oxygenation drops in the first $4-6 \mathrm{~h}$ of life following $\mathrm{HI}$ injury and recovers by $18-20 \mathrm{~h}$ (56). This post-HI drop in cerebral oxygenation was less evident in infants who subsequently develop brain injury (61). Peng et al. described a significant difference in cerebral oxygenation from birth till first $12 \mathrm{~h}$ of life between groups with evidence or absence of injury on MRI (56), while Lemmers et al. indicated a significant difference from $24 \mathrm{~h}$ onwards between groups of favorable and adverse neurodevelopmental outcomes at 2 years of age (48). The sensitivity and specificity of cerebral oxygenation to predict the adverse outcome within the first $10 \mathrm{~h}$ of TH were 100 and $83 \%$ in the study by Peng et al. (56). Lemmers et al. identified the highest predictive value at $24-30 \mathrm{~h}$ of life with a sensitivity of $92 \%$ and specificity of $64 \%$ (48). Higher cerebral oxygenation between 24 and $36 \mathrm{~h}$ of life also significantly increased the odds of having moderate to severe injury on MRI (45). This increased cerebral oxygenation is likely to be related to mitochondrial dysfunction or injury, reflected by decreased oxygen utilization. In addition, vasoparesis and luxury perfusion in the "secondary energy failure" stage, with cerebral perfusion exceeding the metabolic demand results in higher cerebral oxygenation in infants with severe injury.

Van Bel et al. reviewed cerebral hemodynamics and oxygenation responses in babies with HIE (18) in the prehypothermic era - $\mathrm{CBV}, \mathrm{HbO}_{2}$, and $\mathrm{HbR}$ (deoxy-hemoglobin) decreased in the first $12 \mathrm{~h}$ of life in severely asphyxiated infants with the parameters becoming more stable between 12 and $24 \mathrm{~h}$ of life. Meek et al. also noted increased CBF and CBV on the 1st day of life in infants with severe HIE at presentation (Sarnat stage III) (2). These findings were further supported by the study from Nakamura et al. (54). CBV was significantly higher in the poor outcome group (three cooled and two non-cooled infants) at $6 \mathrm{~h}$ of age and by $24 \mathrm{~h}$ of age, cerebral oxygenation was significantly higher in the same group when compared to the infants with favorable outcome based on MRI findings. Cerebral oxygenation together with CBV at $24 \mathrm{~h}$ had a sensitivity, specificity, PPV and NPV of $100 \%$ for the predictive ability for neurological outcome based on MRI findings between 7 and 14 days after birth.

\section{MONITORING MITOCHONDRIAL OXIDATIVE METABOLISM}

Jöbsis in his seminal paper in Science (17) reported a new optical method (NIRS) intended to monitor changes in concentration of cytochrome coxidase along with changes in oxy- and deoxy- hemoglobin for use as a clinical tool. Using a commercial NIRS system (radiometer using four wavelengths-904, 845, 805, and $775 \mathrm{~nm}$ ) van Bel et al. described a decrease in Cytaa $_{3}$ (cytochrome oxidase) with increasing postnatal age in infants with severe HIE in the pre-TH era. Recently, the UCL group monitored $\Delta$ [oxCCO] in a preclinical model using a broadband NIRS (BNIRS) and described a significant correlation between the indicators of brain energy state on phosphorus $\left({ }^{31} \mathrm{P}\right)$ MRS [phosphocreatine/exchangeable phosphate pool ( $\mathrm{PCr} / \mathrm{epp}$ ) and total nucleotide triphosphate/exchangeable phosphate pool (NTP/epp)] and $\Delta$ [oxCCO] during and after HI insult (73). Bale et al. subsequently described a new BNIRS instrument for clinical research (CYRIL, using 136 wavelengths, 770$906 \mathrm{~nm}$ ) (25) and investigated how the relationship between the changes in [oxCCO] and systemic physiology was associated with injury severity (26). Mitra et al. presented a metabolic reactivity index using wavelet analysis (wavelet semblance or phase relationship between two variables) between [oxCCO] and MABP at $48 \mathrm{~h}$ of life during $\mathrm{TH}$ following HIE that differentiated between infants with good and poor outcome (based on MRI scores, thalamic MRS outcome biomarker (Lactate/N-acetyl aspartate) and neurodevelopmental outcome) (52). The relationship between cerebral oxygen delivery and mitochondrial oxidative metabolism also indicated injury severity during TH $(27)$ and rewarming $(51,53)$. Findings from these studies using broadband NIRS are consistent with known pathophysiological changes following HIE and indicate deranged oxidative metabolism resulting from mitochondrial injury and altered hemodynamics associated with the neurochemical cascade effects on cerebrovascular tone.

Fractional tissue oxygen extraction (FTOE, five studies) and cerebral metabolic rate of oxygen consumption $\left(\mathrm{CMRO}_{2}\right.$, two studies) have also been used to monitor cerebral oxidative metabolism. FTOE decreased from $24 \mathrm{~h}$ of age in the adverse outcome group as compared with the favorable outcome group in two studies from the Utrecht group in the cooling and precooling era $(15,48)$, indicating an inability to utilize available oxygen due to more severe mitochondrial injury. Using an FDNIRS-DCS system, the Harvard group $(35,41)$ successfully monitored $\mathrm{CBF}$ and calculated $\mathrm{CMRO}_{2}$ using Fick's principle. Increased $\mathrm{CMRO}_{2}$ and $\mathrm{CBV}$ were more sensitive markers of evolving neuronal injury compared to brain tissue oxygenation in a cohort of infants with evidence of brain injury on ultrasound and MRI following HIE (3 cases) and other etiologies in the precooling era (41). A subsequent study from the same group in a cohort of infants undergoing TH (10 infants with HIE and 17 matched control infants) (35) presented lower $\mathrm{CMRO}_{2}$ and $\mathrm{CBF}$ and high $\mathrm{CBV}$ in infants during $\mathrm{TH}$ compared to control infants and post- $\mathrm{TH}$ values. The reason for difference in findings of $\mathrm{CMRO}_{2}$ was not clear, but $\mathrm{CMRO}_{2}$ depends on $\mathrm{CBF}$ which was also low in the second study and was not recorded in the first study. In the first study, all three infants had a severe injury (intensive care withdrawn in two cases and the third case developed significant impairment), but in the second study, eight infants had a comparatively milder injury (either normal MRI or decreased apparent diffusion coefficient (ADC) in the cortex and white matter). The neurodevelopmental outcome in the second study at 18 months of age (56.6\% normal outcome) 
was similar to those reported in the literature. The findings in the different neurodevelopmental groups were not explored in this study. Elevated CBV during $\mathrm{TH}$ was noted (consistent with previous studies) although $\mathrm{CBF}$ was decreased. Possible effects of medications (e.g., dopamine) and deranged cerebral autoregulation following HIE were discussed as possible factors contributing to these findings.

\section{MONITORING CEREBRAL AUTOREGULATION}

Cerebral autoregulation refers to the physiological ability of the healthy brain to maintain a steady cerebral blood flow $(\mathrm{CBF})$ during changes in cerebral perfusion pressure (CPP). In view of the difficulty in direct measurement of invasive $\mathrm{CPP}$, mean arterial blood pressure (MABP) is used as a proxy marker in neonatal studies. The relationship between cerebral oxygenation (as a marker of changes in CBF) or total hemoglobin concentration (as a marker of total blood volume) and MABP has been used to determine the autoregulatory capacity of the newborn brain both in time and frequency domain analysis. Cerebral vasoparesis following perinatal hypoxia ischaemia is associated with impaired pressure autoregulation leading to poor outcome (2). Failure to regulate CBF during changes in MABP following HIE can lead to the uncoupling of the tight relationship between $\mathrm{CBF}$ and cerebral energy metabolism and results in further injury during secondary energy failure.

Nine studies investigated changes in different cerebrovascular reactivity indices in relation to outcome. Massaro et al. (49) used spectral coherence that quantifies the relationship between changes in MABP and changes in $\mathrm{HbD}$ to identify pressurepassive cerebrovascular circulation indicated by increased coherence between the two physiological signals. Pressure passivity index (PPI) and gain were used for quantification of the duration and magnitude of cerebral pressure passivity, respectively. Infants with poor outcome (evidence of injury on MRI) exhibited higher PPI and gain, indicating longer duration and higher magnitude of cerebral pressure passivity following hypoxia-ischemia. Howlett et al. used a time domainbased reactivity index between hemoglobin volume and MABP $(\mathrm{HVx})$ to identify an optimal blood pressure $\left(\mathrm{MAP}_{\mathrm{OPT}}\right)$ where vasoreactivity is greatest (43). A greater severity of brain injury was associated with more time spent with MABP below $\mathrm{MAP}_{\mathrm{OPT}}$ during rewarming, while neonates with evidence of no or mild injury spent more time with MABP within or above MAP $\mathrm{OPT}_{\mathrm{O}}$. Burton et al. used the same index $(\mathrm{HVx})$ and followed up 19 infants to 2 years of age (29). Infants with poor outcome at 2 years had higher MAP ${ }_{\text {OPT }}$ values, spent more time with MABP below MAP ${ }_{\mathrm{OPT}}$ and had greater MABP deviation below MAP ${ }_{\mathrm{OPT}}$ during rewarming. Also, infants with greater MABP deviation above $\mathrm{MAP}_{\mathrm{OPT}}$ had lesser disability and higher cognitive scores. Lee et al. from the same group reviewed the role of $\mathrm{HVx}$ in a larger cohort of 64 infants and confirmed that greater duration and deviation of MABP below $\mathrm{MAP}_{\mathrm{OPT}}$ were associated with greater injury in the white matter and paracentral gyri on MRI. MABP within $\mathrm{MAP}_{\mathrm{OPT}}$ was associated with lesser injury in the white matter, putamen and globus pallidus, and brain stem (47). Restricted diffusion (characterized by low ADC values) in the posterior centrum semiovale and the posterior limb of the internal capsule correlated with MABP deviation below the $\mathrm{MAP}_{\mathrm{OPT}}$ during hypothermia was also observed (61). Lower ADC scalars in the basal ganglia correlated with worse autoregulation during rewarming after $\mathrm{TH}$.

Chalak et al. reviewed the dynamic and multiple-timescale properties of cerebral autoregulation with a moving time window correlation between cerebral oxygenation and MABP and demonstrated the presence of large spontaneous fluctuations in MABP during TH in the infants with abnormal outcome (31). Both in-phase and antiphase correlations were associated with poor outcome. Tian et al. from the same group used wavelet analysis to understand and characterize the cerebrovascular reactivity in both time and frequency domain (62). The timescale dependent nature of dynamic cerebral autoregulation was described with both in-phase and anti-phase coherence between the spontaneous oscillations in MABP and cerebral oxygenation. Findings were similar to their previous study (31). Mitra et al. presented a refined wavelet analysis technique and described a metabolic and haemodynamic reactivity index (wavelet semblance or phase difference between [oxCCO] and MABP or [HbD] and MABP]) in relation to outcome (52).

These findings highlight the importance of appropriate haemodynamic management following HIE for the prevention of secondary brain injury. This potential benefit of optimizing haemodynamic management using NIRS based reactivity indices requires validation.

\section{CEREBRAL NIRS MARKERS AND NEURODEVELOPMENTAL OUTCOME}

Fifteen studies have included a neurodevelopmental follow up data to compare the NIRS based indices for outcome prognostication. Meek et al. followed up a cohort of infants following HIE to 1 year of age and noted a raised CBV in the adverse outcome group on day 1 (2). Toet et al. followed up their cohort up to 5 years of age using the Griffiths Mental Developmental Scale to identify the favorable and unfavorable groups in the pre-TH era (15). The same group has subsequently reviewed the prognostic value of cerebral oxygenation and FTOE in the cooling era in a cohort of 39 infants and noted significant differences in both cerebral oxygenation and FTOE between the good and adverse outcome groups (48). These findings have been discussed previously. Interestingly, in a study cohort of 18 infants (57), no definite relationship was noted by Shellhaas et al. between cerebral oxygenation and neurodevelopmental outcome at 18 months. Differences of these findings compared to previous studies can be related to: (a) smaller sample size; (b) decisions to withdraw intensive care were different; in the other two studies $(15,48)$ as most infants with a predicted adverse outcome died after redirection of care during the neonatal period; (c) use of different neurodevelopmental assessment tools-Shellhass et al. 
used Bayley Scales of Infant Development, Lemmers et al. and Toet et al. both used Griffiths Mental Developmental scales; and (d) use of different NIRS sensors-neonatal sensors were used by Shellhass et al. while the other studies used pediatric sensors. Different NIRS sensors are known to cause differences in absolute values of cerebral oxygenation $(74,75)$. Neonatal sensors tend to record tissue saturations higher than adult sensor (in case of INVOS NIRS monitors, this is $\sim 10 \%)$. As most monitors have the upper limit set to $95 \%$, higher values recorded by neonatal sensors can present in a straight line over time, without much variability.

Ancora et al. (23) noted a significantly higher cerebral oxygenation value at $12 \mathrm{~h}$ of age in infants with the adverse outcome on a 1-year Griffiths assessment. A trend toward higher values in the adverse outcome group was also observed at 6-and 24-h during TH. Similar findings were reported also by Zaramella et al. using the Amiel-Tison score at 1 year of age (65). Two recent studies $(52,62)$ using wavelet analysis also noted a clear difference in NIRS biomarkers between good and poor outcome infants based on their neurodevelopment assessment scores.

\section{NIRS MONITORING WITH OTHER NEUROMONITORING TOOLS}

Fifteen studies combined NIRS monitoring with structural and haemodynamic changes on MRI and metabolic derangement on thalamic ${ }^{1} \mathrm{H}$ MRS while eight studies reviewed background electrical activity on aEEG together with NIRS.

Shellhas et al. (57), Peng et al. (56), and Mitra et al. (52) used different MRI scores to review the relationship between NIRS biomarkers with short term outcome. Massaro et al. (49) compared a measurement of CBF on Arterial spin labeling (ASL) MR imaging between 7 and 10 days with FTOE on day 1 (during cooling) and on day 4 (after rewarming) in infants with HIE and healthy controls. Infants with HIE had lower FTOE on both days (significantly lower after rewarming). Regional CBF on ASL in the basal ganglia thalamic (BGT) region and anterior white matter (AWM) was higher in the HIE cohort. However, $\mathrm{CBF}$ in BGT area in infants with no evidence of injury on MR imaging or watershed type of injury following HIE was higher in comparison to infants with confirmed evidence of injury in basal ganglia and focal/multifocal injury in the WM. The lack of hyperperfusion was thought to be related to the pseudonormalisation of $\mathrm{CBF}$ and low metabolic demand after the development of an irreversible injury. Wintermark et al. (63) further investigated the relationship between brain perfusion measured by NIRS and ASL-MRI. A strong correlation was noted between cerebral oxygenation and CBF measured with ASL MRI (mean CBF from both frontal lobes) in infants with severe HIE, although no significant correlation was found when both groups of infants with moderate and severe HIE were combined together. This study also demonstrated that infants with severe HIE had lower CBF and lower oxygen extraction compared to those with moderate HIE.

Tekes et al. reviewed the relationship between a NIRS marker of cerebrovascular reactivity $(\mathrm{HVx})$ with diffusion weighted $\mathrm{MR}$ imaging (61). Blood pressure deviation from MABP ${ }_{\mathrm{OPT}}$ (using $\mathrm{HVx}$ ) was associated with low ADC scalers in the posterior limb of internal capsule (PLIC) and posterior centrum semiovale on MRI performed on day 10 of life or later. Howlett et al. used the same index to identify the optimal blood pressure that relates to outcome based on MRI findings (43). Mitra et al. used wavelet based NIRS reactivity indices to describe the relationship with proton $\left({ }^{1} \mathrm{H}\right)$ MRS derived thalamic Lac/NAA (52).

The first study combining NIRS and aEEG monitoring was reported by Ancora et al. (22). A persistently abnormal aEEG at $24 \mathrm{~h}$ of life was not predictive of the adverse outcome but the recovery of electrical activity within this period was associated with good outcome (23). In comparison, high cerebral oxygenation at $12 \mathrm{~h}$ indicated poor neurodevelopmental outcome. In two Dutch studies $(15,48)$, higher cerebral oxygenation and lower aEEG background scores both were subsequently associated with poor outcome. Lemmers et al. were the first to evaluate a combined NIRS (cerebral oxygenation) and aEEG score for the prediction of neurodevelopmental outcome (48). The combined score had a significantly improved positive predictive value (91\%) compared to individual monitoring (cerebral oxygenation 67\%, aEEG 62\%). This combined score helped to predict the outcome as early as $12 \mathrm{~h}$ of age (sensitivity $100 \%$, specificity $87 \%$ ). Improvement in predicting outcome using a combined score was also described by Goeral et al. (38) and Neizen et al. (55). Chalak et al. introduced an estimation of neurovascular coupling (NVC) using wavelet analysis of cerebral oxygenation and aEEG. A few examples were presented as case studies where this wavelet index of NVC was related to outcome (32).

Shellhaas et al. compared cerebral and somatic oxygenation on NIRS and aEEG with a composite score of short-term outcome (using Thompson scores on neurological examination after rewarming and MRI scores) (58). Absolute values of cerebral and somatic oxygenation, as well as the aEEG variables before and during rewarming did not correlate with short term outcome. However, the variability of systemic oxygenation was a good predictor of the short-term outcome, Variability of cerebral oxygenation was not related to outcome. The study presented only the analysis of data $6 \mathrm{~h}$ before rewarming and during the rewarming period $(6 \mathrm{~h})$, although their monitoring included the entire period of $\mathrm{TH}$, rewarming period and $12 \mathrm{~h}$ of normothermia after completion of rewarming. It would have been useful to identify the trend of cerebral oxygenation on days 1-3 during $\mathrm{TH}$ in relation to this new short-term outcome composite score. The authors speculated that the multiorgan dysfunction resulting from HIE was reflected in low systemic oxygenation variability.

\section{FUTURE DIRECTION}

Ideally, an optical neuromonitor in neonatal intensive care should provide continuous information regarding cerebral oxidative metabolism, oxygenation and blood flow in realtime at the cot side. Current studies using commercial NIRS oximeter systems can measure only cerebral oxygenation and in combination with other systemic measurements attempt to 
derive markers of metabolism. However, recent advances in NIRS technology and techniques have allowed the emergence of new directions in optical monitoring that promise to present a better insight into the degree of neural injury. New NIRS monitors that can monitor cerebral oxygenation and blood flow [Babylux: combining DCS and time-resolved reflectance spectroscopy (TRS) (76), Metaox: combining FD-NIRS and DCS (77)], Cyril: monitoring of CCO (BNIRS) and Florence: monitoring of CCO and blood flow together (combining BNIRS and DCS, currently being used by UCL group) are encouraging innovations in this area. There is continued research in the optical community to investigate the validity of existing tissue oximetry algorithms, especially regarding their precision and reproducibility $(46,78)$. New approaches, such as using broadband spectra (72) or novel combinations of spectral and multidistance techniques (79), are being developed to obtain more robust measurements of cerebral oxygenation. Advances in the optical developments to improve the accuracy of the measurement will increase acceptance within the clinical practice. The combination of (as opposed to the individual) measurements of brain tissue mitochondrial function, blood flow, oxygenation, and oxygen consumption will lead to a better assessment of neonatal hypoxic-ischaemic brain injury and most likely to offer enhanced prognostic value. An optical instrument that can deliver these measurements in real-time, non-invasively at the cot-side is necessary, with appropriate analysis techniques that will allow integration of these measurements toward the derivation of clinical information.

A small sample size often limits the validity of the findings of many NIRS studies. Future studies in this field need to be designed with sample size appropriate to answer the clinically relevant questions using measurable outcome parameters. This will provide further confidence in the clinical translation of this technology. Multicenter randomized controlled studies in the preterm population to review the benefit of NIRS monitoring have demonstrated the benefits of the cerebral oximetry monitoring (14), but no similar study has been published for HIE. One of the other complex issues is the use of different NIRS sensors and algorithms used by different manufacturers to measure cerebral oxygenation. Despite the difference in techniques and algorithms, most of the commercial monitors have shown a reasonable correlation between the measured tissue saturation values $(74,80-84)$ but without a uniform terminology, readers struggle to correlate the findings from different studies. Several manufacturers have developed smaller and flexible neonatal sensors but the use of different sensors with the same brain oximeter can produce different measurements, as pointed out by Lemmers et al. and colleagues $(6,74,75)$. So, it is important to specify the type of NIRS oximeter sensor used with their reference values in each study. Finally, quantification of cerebral autoregulation using NIRS and systemic variables can offer a good insight of brain health; however, authors should consider the use of advanced signal processing techniques (e.g., wavelet analysis) to better quantify changes in the context of the dynamic nature of cerebral autoregulation.

\section{LIMITATIONS}

We only reviewed human studies to focus on the assessment of this neuromonitoring technique in the clinical environment. This is a limitation of this review as some important work in preclinical models were not included. The use of the English language as a filter during the search and literature search using two medical databases might have resulted in the omission of some studies, although the chance of missing any major publication in this field will be low.

There are also some inherent limitations of NIRS technology. Any strong light (e.g., halogen spotlight attached to the incubator or a standing spotlight) can cause interference with NIRS monitoring. Hair can also sometimes pose an issue as it can absorb a lot of light, although this is unlikely in newborn infants. Hematoma and significant edema in the layers between skin and the scalp can also cause problems with NIRS recording as they will contribute to the measured signals, reducing the amount of information detected from the brain. Movement artifacts can also be an issue if not carefully documented.

\section{CONCLUSION}

Significant effort has been made over the last decade to examine the role of cerebral NIRS monitoring in HIE. Commercially available cerebral NIRS parameters can identify cerebral hyperoxygenation, increased cerebral perfusion and loss of cerebral autoregulation in infants with severe HIE. Changes in NIRS variables in HIE are associated with subsequent neurodevelopmental outcome. Combined clinical neuromonitoring using NIRS and aEEG/EEG monitoring is feasible and appears to improve the prognostication of the neurodevelopmental outcome. Although the evidence from the currently available studies indicates a positive role for NIRS based neuromonitoring for infants with HIE, these findings need to be reviewed in larger prospective cohorts before translation to clinical practice.

\section{AUTHOR CONTRIBUTIONS}

SM completed the initial literature search. SM and NR assessed the papers and drafted the first review. SM, GB, JM, IT, and NR contributed to the final version.

\section{FUNDING}

The Wellcome Trust (219610/Z/19/Z) and Medical Research Council (MR/S003134/1).

\section{ACKNOWLEDGMENTS}

The authors would like to acknowledge the help from Simon Coats, Clinical Support librarian in UCL medical library for this systematic review. 


\section{REFERENCES}

1. Azzopardi D, Wyatt JS, Cady EB, Delpy DT, Baudin J, Stewart AL, et al. Prognosis of newborn infants with hypoxic-ischemic brain injury assessed by phosphorus magnetic resonance spectroscopy. Pediatr Res. (1989) 25:44551. doi: 10.1203/00006450-198905000-00004

2. Meek JH, Elwell CE, McCormick DC, Edwards AD, Townsend JP, Stewart AL, et al. Abnormal cerebral hemodynamics in perinatally asphyxiated neonates related to outcome. Arch Dis Child Fetal Neonatal Ed. (1999) 81:F110F5. doi: 10.1136/fn.81.2.F110

3. Hassell KJ, Ezzati M, Alonso-Alconada D, Hausenloy DJ, Robertson NJ. New horizons for newborn brain protection: enhancing endogenous neuroprotection. Arch Dis Child Fetal Neonatal Ed. (2015) 100:F54152. doi: 10.1136/archdischild-2014-306284

4. Mitra S, Kendall GS, Bainbridge A, Sokolska M, Dinan M, Uria-Avellanal C, et al. Proton magnetic resonance spectroscopy lactate/ $\mathrm{N}$-acetylaspartate within 2 weeks of birth accurately predicts 2 -year motor, cognitive and language outcomes in neonatal encephalopathy after therapeutic hypothermia. Arch Dis Child Fetal Neonatal Ed. (2019) 104:F42432. doi: 10.1136/archdischild-2018-315478

5. Lally PJ, Montaldo P, Oliveira V, Soe A, Swamy R, Bassett P, et al. Marble consortium. Magnetic resonance spectroscopy assessment of brain injury after moderate hypothermia in neonatal encephalopathy: a prospective multicentre cohort study. Lancet Neurol. (2019) 18:35-45. doi: 10.1016/S1474-4422(18)30325-9

6. Dix LM, van Bel F, Lemmers PM. Monitoring cerebral oxygenation in neonates: an update. Front Pediatr. (2017) 5:46. doi: 10.3389/fped.2017.00046

7. Garvey AA, Dempsey EM. Applications of near infrared spectroscopy in the neonate. Curr Opin Pediatr. (2018) 30:20915. doi: $10.1097 / \mathrm{MOP} .0000000000000599$

8. Almaazmi M, Schmid MB, Havers S, Reister F, Lindner W, Mayer B, et al. Cerebral near-infrared spectroscopy during transition of healthy term new-borns. Neonatology. (2013) 103:246-51. doi: 10.1159/000 345926

9. Urlesberger B, Kratky E, Rehak T, Pocivalnik M, Avian A, Czihak J, et al. Regional oxygen saturation of the brain during birth transition of term infants: comparison between elective cesarean and vaginal deliveries. J Pediatr. (2011) 159:404-8. doi: 10.1016/j.jpeds.2011.02.030

10. Baik N, Urlesberger B, Schwaberger B, Schmolzer GM, Mileder L, Avian $A$, et al. Reference ranges for cerebral tissue oxygen saturation index in term neonates during immediate neonatal transition after birth. Neonatology. (2015) 108:283-6. doi: 10.1159/000438450

11. Bailey SM, Hendricks-Munoz KD, Mally P. Cerebral, renal, and splanchnic tissue oxygen saturation values in healthy term newborns. Am J Perinatol. (2014) 31:339-44. doi: 10.1055/s-0033-1 349894

12. McNeill S, Gatenby JC, McElroy S, Engelhardt B. Normal cerebral, renal and abdominal regional oxygen saturations using near-infrared spectroscopy in preterm infants. J Perinatol. (2011) 31:51-7. doi: 10.1038/jp.2010.71

13. Roche-Labarbe N, Carp SA, Surova A, Patel M, Boas DA, Grant PE, et al. Noninvasive optical measures of $\mathrm{CBV}, \mathrm{StO}_{2}, \mathrm{CBF}$ index, and $\mathrm{rCMRO}_{2}$ in human premature neonates brains in the first six weeks of life. Hum Brain Mapp. (2010) 31:341-52. doi: 10.1002/hbm.20868

14. Hyttel-Sorensen S, Pellicer A, Alderliesten $\mathrm{T}$, Austin $\mathrm{T}$, van Bel F, Benders $\mathrm{M}$, et al. Cerebral near infrared spectroscopy oximetry in extremely preterm infants: phase II randomised clinical trial. BMJ. (2015) 350:g7635. doi: 10.1136/bmj.g7635

15. Toet MC, Lemmers PMA, van Schelven LJ, van Bel F. Cerebral oxygenation and electrical activity after birth asphyxia: their relation to outcome. Pediatrics. (2006) 117:333-9. doi: 10.1542/peds.2005-0987

16. Edwards AD, Brown GC, Cope M, Wyatt JS, McCormick DC, Roth SC, et al. Quantification of concentration changes in neonatal human cerebral oxidized cytochrome oxidase. J Appl Physiol. (1985) 71:190713. doi: 10.1152/jappl.1991.71.5.1907

17. Jöbsis FF. Noninvasive, infrared monitoring of cerebral and myocardial oxygen sufficiency and circulatory parameters. Science. (1977) 198:12647. doi: $10.1126 /$ science. 929199
18. Van Bel F, Dorrepaal CA, Benders MJNL, Zeeuwe PEM, Van de Bor M, Berger HM. Changes in cerebral hemodynamics and oxygenation in the first 24 hours after birth asphyxia. Pediatrics. (1993) 92:365-72.

19. Bale G, Elwell CE, Tachtsidis I. From Jöbsis to the present day: a review of clinical near-infrared spectroscopy measurements of cerebral cytochrome-coxidase. J Biomed Opt. (2016) 21:099801. doi: 10.1117/1.JBO.21.9.099801

20. Korček P, Stranák Z, Širc J, Naulaers G. The role of near-infrared spectroscopy monitoring in preterm infants. J Perinatol. (2017) 37:107077. doi: $10.1038 /$ jp.2017.60

21. Liberati A, Altman DG, Tetzlaff J, Mulrow C, Gøtzsche PC, Ioannidis JP, et al. The PRISMA statement for reporting systematic reviews and meta-analyses of studies that evaluate healthcare interventions: explanation and elaboration. PLoS Med. (2009) 6:e1000100. doi: 10.1371/journal.pmed.1000100

22. Ancora G, Maranella E, Locatelli C, Pierantoni L, Faldella G. Changes in cerebral hemodynamics and amplitude integrated EEG in an asphyxiated newborn during and after cool cap treatment. Brain Dev. (2009) 31:4424. doi: 10.1016/j.braindev.2008.06.003

23. Ancora G, Maranella E, Grandi S, Sbravati F, Coccolini E, Savini $\mathrm{S}$, et al. Early predictors of short term neurodevelopmental outcome in asphyxiated cooled infants. A combined brain amplitude integrated electroencephalography and near infrared spectroscopy study. Brain Dev. (2013) 35:26-31. doi: 10.1016/j.braindev.2011.09.008

24. Arriaga-Redondo M, Arnaez J, Benavente-Fernández I, Lubián-López S, Hortigüela M, Vega-Del-Val C, et al. Lack of variability in cerebral oximetry tendency in infants with severe hypoxic-ischemic encephalopathy under hypothermia. Ther Hypothermia Temp Manag. (2019) 9:24350. doi: $10.1089 /$ ther.2018.0041

25. Bale G, Mitra S, Meek J, Robertson N, Tachtsidis I. A new broadband near-infrared spectroscopy system for in-vivo measurements of cerebral cytochrome-c-oxidase changes in neonatal brain injury. Biomed Opt Express. (2014) 5:3450-66. doi: 10.1364/BOE.5.003450

26. Bale G, Mitra S, de Roever I, Chan M, Caicedo-Dorado A, Meek $\mathrm{J}$, et al. Interrelationship between broadband NIRS measurements of cerebral cytochrome C oxidase and systemic changes indicates injury severity in neonatal encephalopathy. Adv Exp Med Biol. (2016) 923:1816 doi: 10.1007/978-3-319-38810-6_24

27. Bale G, Mitra S, de Roever I, Sokolska M, Price D, Bainbridge A, et al. Oxygen dependency of mitochondrial metabolism indicates outcome of newborn brain injury. J Cereb Blood Flow Metab. (2018) 39, 20352047. doi: $10.1177 / 0271678 X 18777928$

28. Bale G, Taylor N, Mitra S, Sudakou A, de Roever I, Meek J, et al. Nearinfrared spectroscopy measured cerebral blood flow from spontaneous oxygenation changes in neonatal brain injury. Adv Exp Med Biol. (2020) 1232:3-9. doi: 10.1007/978-3-030-34461-0_1

29. Burton VJ, Gerner G, Cristofalo E, Chung SE, Jennings JM, Parkinson C, et al. A pilot cohort study of cerebral autoregulation and 2year neurodevelopmental outcomes in neonates with hypoxic-ischemic encephalopathy who received therapeutic hypothermia. BMC Neurology. (2015) 15:209. doi: 10.1186/s12883-015-0464-4

30. Campbell H, Govindan RB, Kota S, Al-Shargabi T, Metzler M, Andescavage $\mathrm{N}$, et al. Autonomic dysfunction in neonates with hypoxic ischemic encephalopathy undergoing therapeutic hypothermia impairs physiological responses to routine care events. J Pediatr. (2018) 196:38-44. doi: 10.1016/j.jpeds.2017.12.071

31. Chalak LF, Tian F, Tarumi T, Zhang R. Cerebral hemodynamics in asphyxiated newborns undergoing hypothermia therapy: pilot findings using a multiple-time-scale analysis. Pediatr. Neurol. (2016) 55:30-6. doi: 10.1016/j.pediatrneurol.2015.11.010

32. Chalak LF, Tian F, Adams-Huet B, Vasil D, Laptook A, Tarumi T, et al. Novel wavelet real time analysis of neurovascular coupling in neonatal encephalopathy. Sci Rep. (2017) 7:45958. doi: 10.1038/srep 45958

33. Chen S, Sakatani K, Lichty W, Ning P, Zhao S, Zuo H. Auditory-evoked cerebral oxygenation changes in hypoxic-ischemic encephalopathy of newborn infants monitored by near infrared spectroscopy. Early Hum Dev. (2002) 67:113-21. doi: 10.1016/S0378-3782(02)0 0004-X 
34. Chock VY, Frymoyer A, Yeh CG, Van Meurs KP. Renal saturation and acute kidney injury in neonates with hypoxic ischemic encephalopathy undergoing therapeutic hypothermia.J Pediatr. (2018) 200:232-9.e1. doi: 10.1016/j.jpeds.2018.04.076

35. Dehaes M, Aggarwal A, Lin PY, Rosa Fortuno C, Fenoglio A, RocheLabarbe $\mathrm{N}$, et al. Cerebral oxygen metabolism in neonatal hypoxic ischemic encephalopathy during and after therapeutic hypothermia. J Cerebr Blood Flow Metab. (2014) 34:87-94. doi: 10.1038/jcbfm.2013.165

36. Forman E, Breatnach CR, Ryan S, Semberova J, Miletin J, Foran A, et al. Noninvasive continuous cardiac output and cerebral perfusion monitoring in term infants with neonatal encephalopathy: assessment of feasibility and reliability. Pediatr Res. (2017) 82:789-95. doi: 10.1038/pr.2017.154

37. Gagnon $\mathrm{MH}$, Wintermark P. Effect of persistent pulmonary hypertension on brain oxygenation in asphyxiated term newborns treated with hypothermia. J Matern Fetal Neonatal Med. (2016) 29:2049-55. doi: 10.3109/14767058.2015.1077221

38. Goeral K, Urlesberger B, Giordano V, Kasprian G, Wagner M, Schmidt L, et al. Prediction of outcome in neonates with hypoxic-ischemic encephalopathy II: role of amplitude-integrated electroencephalography and cerebral oxygen saturation measured by near-infrared spectroscopy. Neonatology. (2017) 112:193-202. doi: 10.1159/000468976

39. Govindan RB, AN Massaro N, Andescavage NN, Chang T, du Plesis A. Cerebral pressure passivity in newborns with encephalopathy undergoing therapeutic hypothermia. Front Hum Neurosci. (2014) 8:266. doi: 10.3389/fnhum.2014.00266

40. Govindan RB, Massaro A, Chang T, Vezina G, du Plessis A. A novel technique for quantitative bedside monitoring of neurovascular coupling. J Neurosci Methods. (2016) 259:135-42. doi: 10.1016/j.jneumeth.2015.11.025

41. Grant PE, Roche-Labarbe N, Surova A, Themelis G, Selb J, Warren $\mathrm{EK}$, et al. Increased cerebral blood volume and oxygen consumption in neonatal brain injury. J Cerebr Blood Flow Metab. (2009) 29:170413. doi: $10.1038 /$ jcbfm. 2009.90

42. Gucuyener K, Beken S, Ergenekon E, Soysal S, Hirfanoglu T, Turan O, et al. Use of amplitude-integrated electroencephalography (aEEG) and near infrared spectroscopy findings in neonates with asphyxia during selective head cooling. Brain Dev. (2012) 34:280-6. doi: 10.1016/j.braindev.2011.06.005

43. Howlett JA, Northington FJ, Gilmore MM, Tekes A, Huisman TAGM, Parkinson C, et al. Cerebrovascular autoregulation and neurologic injury in neonatal hypoxic-ischemic encephalopathy. Pediatr Res. (2013) 74:52535. doi: 10.1038/pr.2013.132

44. Huang L, Ding H, Hou X, Zhou C, Wang G, Tian F. Assessment of the hypoxic-ischemic encephalopathy in neonates using non-invasive near-infrared spectroscopy. Physiol Meas. (2004) 25:749-61. doi: 10.1088/0967-3334/25/3/014

45. Jain SV, Pagano L, Gillam-Krakauer M, Slaughter JC, Pruthi S, Engelhardt B. Cerebral regional oxygen saturation trends in infants with hypoxic-ischemic encephalopathy. Early Hum Dev. (2017) 113:55-61. doi: 10.1016/j.earlhumdev.2017.07.008

46. Kovacsova Z, Bale G, Mitra S, Meek J, Robertson N, Tachtsidis I. Investigation of confounding factors in measuring tissue saturation with NIRS spatially resolved spectroscopy. Adv Exp Med Biol. (2018) 1072:30712. doi: 10.1007/978-3-319-91287-5_49

47. Lee JK, Poretti A, Perin J, Huisman TAGM, Parkinson C, ChavezValdez R, et al. Optimizing cerebral autoregulation may decrease neonatal regional hypoxic-ischemic brain injury. Dev Neurosci. (2017) 39:24856. doi: 10.1159/000452833

48. Lemmers PMA, Zwanenburg RJ, Benders MJNL, De Vries LS, Groenendaal F, Van Bel F, et al. Cerebral oxygenation and brain activity after perinatal asphyxia: does hypothermia change their prognostic value? Pediatr Res. (2013) 74:180-5. doi: 10.1038/pr.2013.84

49. Massaro AN, Bouyssi-Kobar M, Chang T, Vezina LG, Du Plessis AJ, Limperopoulos C. Brain perfusion in encephalopathic newborns after therapeutic hypothermia. Am J Neuroradiol. (2013) 34:1649-55. doi: 10.3174/ajnr.A3422

50. Massaro AN, Govindan RB, Vezina G, Chang T, Andescavage NN, Wang Y, et al. Impaired cerebral autoregulation and brain injury in newborns with hypoxic-ischemic encephalopathy treated with hypothermia. J Neurophysiol. (2015) 114:818-24. doi: 10.1152/jn.00353.2015
51. Mitra S, Bale G, Meek J, Uria-Avellanal C, Robertson NJ, Tachtsidis I. Relationship between cerebral oxygenation and metabolism during rewarming in newborn infants after therapeutic hypothermia following hypoxic-ischemic brain injury. Adv Exp Med Biol. (2016) 923:24551. doi: 10.1007/978-3-319-38810-6_33

52. Mitra S, Bale G, Highton D, Gunny R, Uria-Avellanal C, Bainbridge A, et al. Pressure passivity of cerebral mitochondrial metabolism is associated with poor outcome following perinatal hypoxic ischemic brain injury. J Cereb Blood Flow Metab. (2017) 1:271678X17733639. doi: 10.1177/0271678X17733639

53. Mitra S, Bale G, de Roever I, Meek J, Robertson NJ, Tachtsidis I. Changes in brain tissue oxygenation and metabolism during rewarming after neonatal encephalopathy are related to electrical abnormality. Adv Exp Med Biol. (2020) 1232:25-31. doi: 10.1007/978-3-030-34461-0_4

54. Nakamura S, Koyano K, Jinnai W, Hamano S, Yasuda S, Konishi $\mathrm{Y}$, et al. Simultaneous measurement of cerebral hemoglobin oxygen saturation and blood volume in asphyxiated neonates by near-infrared time-resolved spectroscopy. Brain Dev. (2015) 37:925-32. doi: 10.1016/j.braindev.2015.04.002

55. Niezen CK, Bos AF, Sival DA, Meiners LC, Ter Horst HJ. Amplitude-integrated EEG and cerebral near-infrared spectroscopy in cooled, asphyxiated infants. Am J Perinatol. (2018) 35:90410. doi: 10.1055/s-0038-1626712

56. Peng S, Boudes E, Tan X, Saint-Martin C, Shevell M, Wintermark P. Does near-infrared spectroscopy identify asphyxiated newborns at risk of developing brain injury during hypothermia treatment? Am J Perinatol. (2015) 32:555-64. doi: 10.1055/s-0034-1396692

57. Shellhaas RA, Thelen BJ, Bapuraj JR, Burns JW, Swenson AW, Christensen MK, et al. Limited short-term prognostic utility of cerebral NIRS during neonatal therapeutic hypothermia. Neurology. (2013) 81:24955. doi: 10.1212/WNL.0b013e31829bfe41

58. Shellhaas RA, Burns JW, Wiggins SA, Christensen MK, Barks JD, Chervin RD. Sleep-wake cycling and cerebral oxygen metabolism among critically ill neonates. J Child Neurol. (2014) 29:530-3. doi: 10.1177/0883073812470972

59. Shellhaas RA, Kushwaha JS, Plegue MA, Selewski DT, Barks JD. An evaluation of cerebral and systemic predictors of 18-month outcomes for neonates with hypoxic ischemic encephalopathy. J Child Neurol. (2015) 30:152631. doi: $10.1177 / 0883073815573319$

60. Tax N, Urlesberger B, Binder C, Pocivalnik M, Morris N, Pichler G. The influence of perinatal asphyxia on peripheral oxygenation and perfusion in neonates. Early Hum Dev. (2013) 89:483-6. doi: 10.1016/j.earlhumdev.2013.03.011

61. Tekes A, Poretti A, Scheurkogel MM, Huisman TAGM, Howlett JA, Alqahtani E, et al. Apparent diffusion coefficient scalars correlate with near-Infrared spectroscopy markers of cerebrovascular autoregulation in neonates cooled for perinatal hypoxic-Ischemic injury. Am J Neuroradiol. (2015) 36:18893. doi: 10.3174/ajnr.A4083

62. Tian F, Tarumi T, Liu H, Zhang R, Chalak L. Wavelet coherence analysis of dynamic cerebral autoregulation in neonatal hypoxicischemic encephalopathy. NeuroImage: Clin. (2016) 11:12432. doi: 10.1016/j.nicl.2016.01.020

63. Wintermark P, Hansen A, Warfield SK, Dukhovny D, Soul JS. Near-infrared spectroscopy versus magnetic resonance imaging to study brain perfusion in newborns with hypoxic-ischemic encephalopathy treated with hypothermia. NeuroImage. (2014) 85:287-93. doi: 10.1016/j.neuroimage.2013.04.072

64. Wu TW, Tamrazi B, Soleymani S, Seri I, Noori S. Hemodynamic changes during rewarming phase of whole-body hypothermia therapy in neonates with hypoxic-ischemic encephalopathy.J Pediatr. (2018) 197:6874.e2 doi: 10.1016/j.jpeds.2018.01.067

65. Zaramella P, Saraceni E, Freato F, Falcon E, Suppiej A, Milan A, et al. Can tissue oxygenation index (TOI) and cotside neurophysiological variables predict outcome in depressed/asphyxiated newborn infants? Early Hum Dev. (2007) 83:483-9. doi: 10.1016/j.earlhumdev.2006.09.003

66. Scholkmann F, Kleiser S, Metz AJ, Zimmermann R, Pavia JM, Wolf U, et al. A review on continuous wave functional near-infrared spectroscopy and imaging instrumentation and methodology. Neuroimage. (2014) 85:627. doi: 10.1016/j.neuroimage.2013.05.004

67. Buttafava M, Martinenghi E, Tamborini D, Contini D, Dalla Mora A, Renna $M$, et al. A compact two-wavelength time-domain NIRS system 
based on SiPM and pulsed diode lasers. IEEE Photonics J. (2017) 9:114. doi: 10.1109/JPHOT.2016.2632061

68. Gunadi S, Leung TS, Elwell CE, Tachtsidis I. Spatial sensitivity and penetration depth of three cerebral oxygenation monitors. Biomed Opt Express. (2014) 5:2896-12. doi: 10.1364/BOE.5.002896

69. Matcher SJ, Elwell CE, Cooper CE, Cope M, Delpy DT. Performance comparison of several published tissue near-infrared spectroscopy algorithms. Anal Biochem. (1995) 227:54-68. doi: 10.1006/abio.1995.1252

70. Suzuki S, Takasaki S, Ozaki T, Kobayashi Y. Tissue oxygenation monitor using NIR spatially resolved spectroscopy. Proc. SPIE 3597, Optical Tomography and Spectroscopy of Tissue III San Hose, CA (1999). doi: 10.1117/12.356862

71. Al-Rawi PG, Smielewski P, Kirkpatrick PJ. Evaluation of a near-infrared spectrometer (NIRO 300) for the detection of intracranial oxygenation changes in the adult head. Stroke. (2001) 32:2492-500. doi: 10.1161/hs1101.098356

72. Yeganeh HZ, Toronov V, Elliott JT, Diop M, Lee TY, St. Lawrence K. Broadband continuous-wave technique to measure baseline values and changes in the tissue chromophore concentrations. Biomed Opt Express. (2012) 3:2761-70. doi: 10.1364/BOE.3.002761

73. Bainbridge A, Tachtsidis I, Faulkner SD, Price D, Zhu T, Baer E, et al. Brain mitochondrial oxidative metabolism during and after cerebral hypoxia-ischemia studied by simultaneous phosphorus magnetic-resonance and broadband near-infrared spectroscopy. Neuroimage. (2014) 102:17383. doi: 10.1016/j.neuroimage.2013.08.016

74. Lemmers PM, Dix LM, Toet MC, van Bel F. Limited short-term prognostic utility of cerebral NIRS during neonatal therapeutic hypothermia. Neurology. (2014) 82:1480-1. doi: 10.1212/01.wnl.0000446829.77267.81

75. Dix LM, van Bel F, Baerts W, Lemmers PM. Comparing nearinfrared spectroscopy devices and their sensors for monitoring regional cerebral oxygen saturation in the neonate. Pediatr Res. (2013) 74:557-63. doi: 10.1038/pr.2013.133

76. Giovannella M, Contini D, Pagliazzi M, Pifferi A, Spinelli L, Erdmann $\mathrm{R}$, et al. BabyLux device: a diffuse optical system integrating diffuse correlation spectroscopy and time-resolved near-infrared spectroscopy for the neuromonitoring of the premature newborn brain. Neurophoton. (2019) 6:025007. doi: 10.1117/1.NPh.6.2.025007

77. Jain V, Buckley EM, Licht DJ, Lynch JM, Schwab PJ, Naim MY, et al. Cerebral oxygen metabolism in neonates with congenital heart disease quantified by MRI and optics. J Cereb Blood Flow Metab. (2014) 34:3808. doi: $10.1038 /$ jcbfm.2013.214
78. Kleiser S, Nasseri N, Andresen B, Greisen G, Wolf M. Comparison of tissue oximeters on a liquid phantom with adjustable optical properties. Biomed Opt Express. (2016) 7:2973-92. doi: 10.1364/BOE.7.002973

79. Kovácsová Z, Bale G, Veesa JD, Dehghani H, Tachtsidis I. A broadband multidistance approach to measure tissue oxygen saturation with continuous wave near-infrared spectroscopy. Proc. SPIE 11074, Diffuse Optical Spectroscopy and Imaging VII, 110740P. Munich (2019). doi: 10.1117/12.252 7180

80. Thavasothy M, Broadhead M, Elwell C, Peters M, Smith M. A comparison of cerebral oxygenation as measured by the NIRO 300 and the INVOS 5100 near-infrared spectrophotometers. Anaesthesia. (2002) 57:999-1006. doi: 10.1046/j.1365-2044.2002.02826.x

81. Nagdyman N, Ewert P, Peters B, Miera O, Fleck T, Berger F. Comparison of different near-infrared spectroscopic cerebral oxygenation indices with central venous and jugular venous oxygen-ation saturation in children. Paediatr Anaesth. (2008) 18:160-6. doi: 10.1111/j.1460-9592.2007. 02365.x

82. Grubhofer G, Tonninger W, Keznickl P, Skyllouriotis P, Ehrlich M, Hiesmayr $\mathrm{M}$, et al. A comparison of the monitors INVOS 3100 and NIRO 500 in detecting changes in cerebral oxygenation. Acta Anaesthesiol Scand. (1999) 43:470-5. doi: 10.1034/j.1399-6576.1999.430417.x

83. Cho H, Nemoto EM, Sanders M, Fernandez K, Yonas H. Comparison of two commercially available near-infrared spectroscopy instruments for cerebral oximetry. Technical note. J Neurosurg. (2000) 93:3514. doi: 10.3171 /jns.2000.93.2.0351

84. Yoshitani K, Kawaguchi M, Tatsumi K, Kitaguchi K, Furuya H. A comparison of the INVOS 4100 and the NIRO 300 near-infrared spectrophotometers. Anesth Analg. (2002) 94:586-90. doi: 10.1097/00000539-200203000-00020

Conflict of Interest: The authors declare that the research was conducted in the absence of any commercial or financial relationships that could be construed as a potential conflict of interest.

Copyright $\odot 2020$ Mitra, Bale, Meek, Tachtsidis and Robertson. This is an openaccess article distributed under the terms of the Creative Commons Attribution License (CC BY). The use, distribution or reproduction in other forums is permitted, provided the original author(s) and the copyright owner(s) are credited and that the original publication in this journal is cited, in accordance with accepted academic practice. No use, distribution or reproduction is permitted which does not comply with these terms. 